\title{
De arbeidsmarkt voor MBO-schoolverlaters: nu en straks : editie 2003
}

Citation for published version (APA):

van Eijs, P. W. L. J. (2003). De arbeidsmarkt voor MBO-schoolverlaters: nu en straks : editie 2003.

Researchcentrum voor Onderwijs en Arbeidsmarkt, Faculteit der Economische Wetenschappen. ROA Reports No. 7 https://doi.org/10.26481/umarep.2003007

Document status and date:

Published: 01/01/2003

DOI:

10.26481/umarep.2003007

Document Version:

Publisher's PDF, also known as Version of record

\section{Please check the document version of this publication:}

- A submitted manuscript is the version of the article upon submission and before peer-review. There can be important differences between the submitted version and the official published version of record.

People interested in the research are advised to contact the author for the final version of the publication, or visit the DOI to the publisher's website.

- The final author version and the galley proof are versions of the publication after peer review.

- The final published version features the final layout of the paper including the volume, issue and page numbers.

Link to publication

\footnotetext{
General rights rights.

- You may freely distribute the URL identifying the publication in the public portal. please follow below link for the End User Agreement:

www.umlib.nl/taverne-license

Take down policy

If you believe that this document breaches copyright please contact us at:

repository@maastrichtuniversity.nl

providing details and we will investigate your claim.
}

Copyright and moral rights for the publications made accessible in the public portal are retained by the authors and/or other copyright owners and it is a condition of accessing publications that users recognise and abide by the legal requirements associated with these

- Users may download and print one copy of any publication from the public portal for the purpose of private study or research.

- You may not further distribute the material or use it for any profit-making activity or commercial gain

If the publication is distributed under the terms of Article $25 \mathrm{fa}$ of the Dutch Copyright Act, indicated by the "Taverne" license above, 


\section{De arbeidsmarkt voor MBO-schoolverlaters: nu en straks}

\section{editie 2003}

ROA-R-2003/7

Patrick van Eijs

Researchcentrum voor Onderwijs en Arbeidsmarkt

Faculteit der Economische Wetenschappen en Bedrijfskunde Universiteit Maastricht

Maastricht, april 2003 
ISBN 90-5321-363-5

Sec03.025.doc 
Inhoud

Bladzijde

Voorwoord

Samenvatting

iii

1 Inleiding 1

2 Na de MBO-opleiding 3

3 MBO'ers aan het werk 11

4 De MBO'er aan het woord 19

5 MBO'ers en de economische onzekerheid 31 



\section{Voorwoord}

Het MBO biedt een gedegen basis voor de arbeidsmarkt. Dat toont het rapport 'De arbeidsmarkt voor MBO-schoolverlaters: nu en straks' weer aan. Het onderzoek is uitgevoerd door het ROA in opdracht van de Bve Raad, de brancheorganisatie van alle onderwijsinstellingen in het middelbaar beroepsonderwijs en de volwasseneneducatie, in het kort bve. In die rol vertegenwoordigt de Raad de belangen van ruim 600.000 deelnemers en 46.000 werknemers.

De samenwerking tussen onderwijs en bedrijfsleven zal geïntensiveerd worden door de nieuwe onderwijsstructuur die het MBO vanaf 2004 kenmerkt. Leerlingen maken kennis met alle facetten van hun toekomstige beroep doordat zij leren in een beroepsspecifieke context.

Hun eerste baan komen veel leerlingen tegen via stage of door het leer/werktraject dat zij volgden in de beroepsbegeleidende leerweg oftewel werkend leren. De stage en leer/werktrajecten zijn dan ook van onschatbare waarde voor het MBO. Niet alleen maken de leerlingen daar kennis met de beroepspraktijk; ze bouwen ook werkervaring op die het bedrijfsleven zeer waardeert.

Het onderzoeksrapport van het ROA laat zien dat het MBO een belangrijke rol speelt als toeleverancier voor de arbeidsmarkt. Ongeveer $40 \%$ van de Nederlandse beroepsbevolking heeft een MBO-diploma op zak. Daarmee wordt de economische betekenis van het MBO onderstreept. Ook heeft het MBO een belangrijke functie in de overstap van MBO naar $\mathrm{HBO}$. In het kader van een leven lang leren stimuleren de onderwijsinstellingen en de overheid leerlingen een vervolgstudie te kiezen. Het HBO is een logische stap voor een toenemend aantal MBO'ers.

Het rapport 'De arbeidsmarkt voor MBO-schoolverlaters: nu en straks' behandelt naast de huidige arbeidsmarktpositie ook uitgebreid de mogelijke gevolgen van de huidige onzekere economische situatie voor de arbeidsmarktpositie van MBO'ers. Ondanks de huidige economische terugslag zal de aanwezigheid van MBO'ers op de arbeidsmarkt noodzakelijk zijn voor de Nederlandse economie.

Het volledige rapport is te vinden en down te loaden van de website van de Bve Raad: www.bveraad.nl. Het aprilnummer van Bve Radius, het magazine van de Bve Raad besteedt aandacht aan het onderzoek.

Ik hoop dat u dit rapport met belangstelling leest.

Margo Vliegenthart

voorzitter Bve Raad 



\section{Samenvatting}

Het middelbaar beroepsonderwijs speelt een belangrijke rol in het Nederlandse onderwijssysteem. Ongeveer de helft van de Nederlandse beroepsbevolking is middelbaar opgeleid. Het aandeel MBO'ers onder de huidige schoolverlaters is zelfs nog groter. Bovendien, en zeker niet in de laatste plaats, vervult het MBO een belangrijke rol in de voorbereiding op het hoger beroepsonderwijs. Een aanzienlijk deel van de HBO'ers zijn doorstromers vanuit het MBO. Onderzoek laat zien dat het middelbaar beroepsonderwijs een sleutelrol vervult in de economische ontwikkeling. In het licht van deze sleutelrol, is een goede aansluiting tussen het middelbaar beroepsonderwijs en de arbeidsmarkt van groot belang. Deze rapportage belicht deze aansluiting tussen het onderwijs en de arbeidsmarkt voor MBO-schoolverlaters.

\section{Economische tegenwind in 2002 voelbaar}

$\mathrm{Na}$ een aantal jaren van grote krapte, laat de arbeidsmarkt voor MBO-schoolverlaters in 2002 de eerste signalen zien van een afnemende vraag naar MBO'ers. Zo loopt, na de uitzonderlijke lage werkloosheid in de jaren 1999 en 2000, de werkloosheid onder MBO-schoolverlaters in 2001 en 2002 weer wat op. In 2000 zat anderhalf jaar na afstuderen nog maar 1,8\% van de MBO'ers die tot de beroepsbevolking gerekend kunnen worden zonder werk, in 2002 is 3,3\% van de schoolverlaters werkloos. In historisch perspectief is dit overigens nog altijd vrij laag. Met name allochtonen en schoolverlaters van BOL-opleidingen op niveau 1 en 2 ondervinden meer moeite om werk te vinden.

Een tweede indicatie voor de minder rooskleurige arbeidsmarkt voor MBO'ers in 2002 biedt de loonontwikkeling. Onder invloed van de krapte op de arbeidsmarkt en de oplopende inflatie stegen de lonen van MBO-schoolverlaters de afgelopen jaren sterk. Aan deze loonstijging is in 2002 een einde gekomen. Vergeleken met 2001 zijn de lonen zelfs met bijna $4 \%$ gedaald.

\section{Werkgever waardeert praktijkervaring BBL'ers}

Hoewel de beroepsopleidende (BOL) en de beroepsbegeleidende leerweg (BBL) beogen de schoolverlaters een gelijkwaardige positie te verschaffen, zijn er uiteraard verschillen. De wat meer op de praktijk gerichte beroepsbegeleidende leerweg legt de nadruk op het aanleren van kennis en vaardigheden in een concrete werksituatie. Werkgevers blijken deze praktijkervaring te waarderen. Wellicht speelt ook de concrete ervaring die de werkgever als leerbedrijf met de BBL'er heeft opgedaan hierbij een rol. Deze waardering komt op verschillende manieren tot uiting. $\mathrm{Na}$ de opleiding vindt de BBL'er sneller werk, krijgt sneller een vaste aanstelling en verdient meer dan de BOL'er. Overigens laat onderzoek zien dat de BOL'ers de achterstand op de BBL'ers snel inhalen. De relatief sterke positie van BBL'ers resulteert in een hoge werksatisfactie. BBL'ers zijn minder vaak op zoek naar ander werk dan BOL'ers. Bovendien zijn BBL'ers meer tevreden over de aansluiting tussen opleiding en beroepspraktijk. 
De positie van MBO'ers met een diploma op niveau 1 of 2 op zak is kwetsbaar. Met name BOL'ers ondervinden de gevolgen van de verslechterende economische situatie. Meer dan $8 \%$ van de BOL'ers niveau 1 en 2 is werkloos. Meer dan $20 \%$ heeft een tijdelijk arbeidscontract. Het percentage tijdelijke contracten is het hoogst voor de sector BOL niveau 1 en 2 economie: ruim $30 \%$.

Zowel BOL'ers als BBL'ers niveau 1 en 2 komen relatief vaak terecht in banen die minder goed aansluiten bij de in de opleiding verworven kennis en vaardigheden. Ze werken vaak onder hun niveau of buiten hun eigen richting. Met name de agrarisch en economisch opgeleiden komen vaak terecht in banen die minder goed aansluiten op de opleiding. Dit betekent veelal dat de schoolverlaters terechtkomen op de zogenaamde 'secundaire arbeidsmarkt' in banen waarvoor nauwelijks of geen scholing vereist is.

\section{Arbeidsmarkt zorgopgeleiden niveau 3 en 4 rooskleurig}

De arbeidsmarkt voor opleidingen op niveau 3 en 4 ziet er over het algemeen veel rooskleuriger uit. De werkloosheid loopt weliswaar iets op, maar is nog steeds laag. De zorgopleidingen springen hierbij in het bijzonder in het oog. De beloning is relatief hoog, het aantal tijdelijke contracten is laag en velen hebben een baan gevonden die goed aansluit bij de opleiding. Met name de economische opleidingen blijven hierbij een beetje achter. De beloning is wat lager en de aansluiting tussen opleiding en beroepspraktijk vaker gebrekkig. Het is dan ook niet verrassend dat de werksatisfactie bij economisch opgeleiden wat lager is dan bij bijvoorbeeld zorgopgeleiden.

\section{Bijna driekwart MBO-schoolverlaters tevreden over huidige functie}

Bijna driekwart van de MBO-schoolverlaters geeft aan (zeer) tevreden te zijn met de huidige functie. Economisch opgeleiden lijken wat minder tevreden dan hun collega's van andere opleidingssectoren. Zorgopgeleiden en schoolverlaters van opleidingen van de sector gedrag en maatschappij zijn relatief tevreden met hun huidige baan. Met name de schoolverlaters van zorgopleidingen hebben door het beroepsspecifieke karakter van de opleiding een duidelijk beeld van de beroepen en instellingen waarin zij terecht komen. Bovendien is hun arbeidsmarktpositie rooskleurig.

\section{BOL'ers kiezen veel vaker voor een vervolgopleiding dan BBL'ers}

BOL'ers kiezen veel vaker voor een vervolgopleiding dan BBL'ers. Over het algemeen kiest bijna de helft van de BOL'ers ervoor om verder te studeren. Een belangrijke uitzondering is de sector $\mathrm{BOL}$ niveau 3 en 4 gezondheidszorg. In deze sectoren kiest slechts bijna $30 \%$ van de schoolverlaters voor een vervolgopleiding. De aanzuigende werking van de arbeidsmarkt, die gekenmerkt wordt door een groot tekort aan zorgopgeleiden, speelt hierbij zeker een rol. Schoolverlaters van de beroepsbegeleidende leerweg kiezen vaak voor de arbeidsmarkt. Over het algemeen kiest meer dan $80 \%$ van de BBL'ers voor de arbeidsmarkt. Dit wijst erop dat BBL'ers 
over het algemeen over meer op de praktijk gerichte vaardigheden beschikken en meer gericht zijn op werk. Ook de band met het leerbedrijf zal hierbij een rol spelen. Met name onder BBL'ers niveau 3 en 4 is de animo om verder te studeren relatief gering.

Ongeveer driekwart van de doorlerende MBO'ers kiest voor een verwante opleiding. Vooral technisch opgeleiden kiezen vaak voor een verwante opleiding. BOL'ers gedrag en maatschappij niveau 3 en 4 kiezen het vaakst voor een opleiding die niet in het verlengde van hun afgesloten opleiding ligt. BBL'ers kiezen wat vaker voor een verwante opleiding dan BOL'ers. BOL'ers kiezen bovendien veel vaker voor een HBOopleiding dan BBL'ers. Vanuit de technische en de zorgopleidingen stroomt slechts ruim $10 \%$ van de BBL'ers niveau 3 en 4 die verder leren door naar het HBO. De nadruk op beroepsgerichte vaardigheden maakt voor BBL'ers de overstap naar een niet-verwante opleiding of een HBO-opleiding wellicht wat moeilijker. Mogelijk speelt ook de relatie met het leerbedrijf een rol. BBL'ers blijven wellicht bij het leerbedrijf en kiezen in overleg met het leerbedrijf een (BBL-)vervolgopleiding. Mogelijk dat door het uitbreiden van de mogelijkheden om een duale opleiding op HBO-niveau te volgen, de doorstroom vanuit BBL-opleidingen naar het $\mathrm{HBO}$ bevorderd wordt.

\section{MBO-opleiding biedt volgens schoolverlaters goede basis}

MBO-schoolverlaters zijn over het algemeen tevreden met hun opleiding. Zo geeft meer dan $80 \%$ van de doorlerende MBO'ers aan tevreden te zijn over de aansluiting tussen de afgeronde opleiding en de vervolgstudie. Met name BOL'ers niveau 3 en 4 zijn wat kritischer. Daarnaast oordeelt $85 \%$ van de werkende MBO-schoolverlaters positief over de aansluiting tussen opleiding en beroepspraktijk. Dit is verrassend hoog, gezien het feit dat volgens objectieve maatstaven zo'n $45 \%$ beneden zijn of haar niveau werkzaam is en ruim een kwart buiten de eigen richting. Een (objectief gezien) gebrekkige aansluiting betekent dus niet per definitie dat de schoolverlater dit als problematisch ervaart.

Dit blijkt ook uit het feit dat een objectief gezien gebrekkige aansluiting niet onmiddellijk leidt tot het actief zoeken naar ander werk. Ruim $12 \%$ van de schoolverlaters is op dit moment actief op zoek naar (ander) werk. Wanneer we kijken naar degenen die beneden hun niveau of buiten hun eigen richting werkzaam zijn, dan levert dat vergelijkbare cijfers op. Hoewel een minder goede aansluiting weldegelijk effect heeft op het zoekgedrag van MBO-schoolverlaters, laten de cijfers ook zien dat slechts $13 \%$ van degenen die onder hun niveau werkzaam zijn en $17 \%$ van degenen die buiten de eigen richting werken dat als een acuut probleem beschouwen en dus actief op zoek zijn naar ander werk.

Ruim driekwart van de MBO-schoolverlaters zou alles achteraf overziende opnieuw voor dezelfde opleiding kiezen. Ook dit is een belangrijke indicatie voor de tevredenheid van de MBO'ers over hun opleiding. BBL'ers niveau 3 en 4 zijn het meest tevreden. Dit is niet zo verrassend gezien hun relatief sterke arbeidsmarktpositie. BOL'ers niveau 1 en 2 zijn het minst vaak tevreden. Schoolverlaters die een baan hebben gevonden die goed aanluit bij de opleiding kijken iets vaker met 
voldoening terug op de opleiding. Met name BOL'ers die beneden hun niveau of buiten hun eigen richting emplooi hebben gevonden hebben wat vaker spijt van de studiekeuze.

MBO'ers hebben behoefte aan meer aandacht voor de praktijk in de opleiding

Ondanks de tevredenheid plaatsen MBO'ers een tweetal kanttekeningen bij hun opleiding. Zij geven aan dat vooral praktische vaardigheden zoals het toepassen van kennis en technieken in de praktijk en het oplossen van problemen meer aandacht verdienen in de opleiding. Ook meer managementachtige vaardigheden zoals het plannen, coördineren en organiseren van activiteiten en het overdragen van kennis blijven volgens MBO-schoolverlaters onderbelicht. Ondanks deze roep om meer aandacht voor de praktijk, geeft ook $37 \%$ aan meer aandacht voor de vakkennis wenselijk te vinden.

Een tweede aandachtspunt wordt gevormd door de studie- en beroepskeuzevoorlichting. Slechts ongeveer $30 \%$ van de MBO'ers geeft aan (zeer) tevreden te zijn over de studie- en beroepskeuzevoorlichting. Met name BOL'ers niveau 3 en 4 vallen in negatieve zin op. BOL'ers niveau 3 en 4 economie zijn het minst tevreden. Slechts $18 \%$ geeft aan (zeer) tevreden te zijn. De ontevredenheid van BOL'ers niveau 3 en 4 kan verschillende oorzaken hebben. BOL'ers hebben wellicht meer mogelijkheden. Zo zijn zij wat minder beroepsspecifiek opgeleid en kiezen zij ook vaker voor het HBO. Deze grotere mogelijkheden maken echter tegelijkertijd de keuze complexer en de behoefte aan begeleiding groter. Een tweede verklaring zou kunnen zijn dat scholen meer aandacht schenken aan kwetsbare groepen die met name opleidingen op niveau 1 en 2 volgen.

\section{Conjunctuur heeft relatief grote invloed op arbeidsmarkt voor MBO-schoolverlaters}

MBO-schoolverlaters zijn in een situatie van economische tegenwind relatief kwetsbaar op de arbeidsmarkt. Dit heeft twee oorzaken. Op de eerste plaats hebben schoolverlaters relatief vaak een tijdelijk contract. Op de tweede plaats vinden MBOschoolverlaters relatief vaak werk in conjunctuurgevoelige bedrijfssectoren als de bouw, de handel, de horeca en de zakelijke dienstverlening, terwijl in sectoren als de overheid en het onderwijs, die veel minder conjunctuurgevoelig zijn, de kansen voor MBO-schoolverlaters relatief klein zijn. Dit geldt met name voor technisch opgeleiden en schoolverlaters van dienstverlenende opleidingen. De keerzijde is dat, wanneer het aantal banen weer groeit, MBO-schoolverlaters erg gewild zijn en ten volle en wellicht sterker dan andere groepen op de arbeidsmarkt kunnen profiteren van een aantrekkende economie. 


\section{$1 \quad$ Inleiding}

Het middelbaar beroepsonderwijs speelt een belangrijke rol in het Nederlandse onderwijssysteem. Bijna de helft van de Nederlandse beroepsbevolking is middelbaar opgeleid. Het aandeel MBO'ers onder de huidige schoolverlaters is zelfs nog groter. Bovendien, en zeker niet in de laatste plaats, vervult het MBO een belangrijke rol in de voorbereiding op het hoger beroepsonderwijs. Een aanzienlijk deel van de HBO'ers zijn doorstromers vanuit het MBO.

Onderzoek laat zien dat het middelbaar beroepsonderwijs een sleutelrol vervult in de economische ontwikkeling. ${ }^{1}$ In landen waar het middelbaar beroepsonderwijs een kleine rol speelt, blijken middelbaar opgeleiden een relatief laag aandeel te hebben in bedrijven. Een voorbeeld vormt Groot-Brittannië. Een internationaal vergelijkend onderzoek op bedrijfsniveau tussen Groot-Britannië en andere landen toont aan dat een geringe vertegenwoordiging van middelbaar opgeleiden een negatieve invloed heeft op de productiviteit in deze bedrijven. Zo is er vaker sprake van vertraging in het productieproces. Ook de kwaliteit van de geleverde goederen en diensten blijkt lager. Dientengevolge blijken Britse ondernemingen hogere overheaduitgaven aan bijvoorbeeld kwaliteitscontrole en planning te maken dan bijvoorbeeld Franse en Duitse bedrijven. Middelbaar opgeleiden blijken bovendien een cruciale rol te spelen in de slagvaardigheid van een organisatie. Een groot aandeel middelbaar (en hoger) opgeleiden resulteert in platte organisatiestructuren, flexibele taakomschrijvingen en een grote nadruk op teamwork en kwaliteitszorg; factoren die een positief effect hebben op de slagvaardigheid van een organisatie.

In het licht van het belang van het middelbaar beroepsonderwijs is een goede aansluiting tussen onderwijs en arbeidsmarkt en een goed verlopende transitie van school naar werk belangrijk. Deze rapportage zal de aansluiting tussen het onderwijs en de arbeidsmarkt voor MBO'ers vanuit een aantal gezichtspunten belichten. De nadruk ligt op het in kaart brengen van de transitie van school naar werk. Hiertoe zal een breed scala aan indicatoren voor de arbeidsmarktpositie van gediplomeerde MBO'ers de revue passeren. Daarnaast zal er, in het licht van de huidige onzekere economische situatie, aandacht worden geschonken aan de conjunctuurgevoeligheid van de werkgelegenheid voor MBO'ers.

Dit rapport richt zich in eerste instantie op degenen die zich in beleidsmatige zin bezighouden met de doorstroom van MBO'ers binnen het onderwijssysteem enerzijds en de arbeidsmarktpositie van gediplomeerde MBO'ers anderzijds. Daarbij wordt met name gedacht aan het (georganiseerde) onderwijsveld, landelijke en regionale overheden, CWI's en sociale partners.

1. Voor een overzicht, zie Heijke, H. (2001), 'Vocational Education from an Economic Point of View', in: Nieuwenhuis, L.F.M. \& W.J. Nijhof (eds), The Dynamics of VET and HRD Systems, Twente University Press, Enschede, pp. 169-180. 
Het rapport is als volgt opgebouwd. Hoofdstuk 2 laat zien wat MBO'ers na het afronden van hun opleiding zijn gaan doen. Hebben ze werk gevonden, hebben ze gekozen voor een vervolgopleiding of zijn ze iets anders gaan doen? Hoofdstuk 3 richt de schijnwerper op de werkende MBO'ers. Onder welke arbeidsvoorwaarden zijn zij aan het werk? Hebben zij een vaste baan? Of heeft de flexibele arbeidsmarkt de laatste jaren aan belang gewonnen? Zit de MBO'er op zijn of haar plek? Of is er sprake van onderbenutting? Of is de MBO'er werkzaam in banen die minder goed aansluiten bij de gevolgde opleidingsrichting? Hoofdstuk 4 neemt de tevredenheid van de MBO-schoolverlater onder de loep. Sluit de opleiding goed aan bij de beroepspraktijk of bij de vervolgopleiding? Is men tevreden met het werk? Of is men op zoek naar een (andere) baan? En zou men, terugkijkend, opnieuw voor dezelfde opleiding hebben gekozen? De baantevredenheid en de eventuele spijt over de studiekeuze worden in het bijzonder bekeken in relatie tot de aansluiting tussen opleiding en beroepspraktijk. Ten slotte wordt, mede in het licht van de huidige onzekere economische situatie, in hoofdstuk 5 stilgestaan bij de vraag hoe vatbaar de werkgelegenheid voor MBOschoolverlaters is voor conjuncturele schommelingen.

Twee onderzoeken liggen aan de in dit rapport gepresenteerde cijfers ten grondslag. In de eerste plaats het schoolverlateronderzoek RUBS (Registratie van Uitstroom en Bestemming van Schoolverlaters), gericht op schoolverlaters van het algemeen voortgezet onderwijs (MAVO, HAVO, VWO), het voorbereidend beroepsonderwijs (VBO) en de beroepsopleidende (BOL) en beroepsbegeleidende (BBL) leerwegen van het secundair beroepsonderwijs. RUBS maakt deel uit van een geïntegreerd monitoringinstrument van de transitie van school naar werk over de volle breedte van het onderwijs. De schoolverlaters worden ongeveer anderhalf jaar na het verlaten van de opleiding ondervraagd middels een schriftelijke vragenlijst. Deze vragenlijst bestaat ut een gedeelte dat voor elke onderwijssoort identiek is en uit een variabel gedeelte waarbij de inhoud afhankelijk is van de onderwijssoort en/of de opleidingssector. Bij BOL en BBL ligt de nadruk voornamelijk op de intrede op de arbeidsmarkt.

Dit jaar is de vragenlijst ingrijpend veranderd. Het resultaat is een beknopte en meer gebruikersvriendelijke vragenlijst. Deze verandering heeft het gewenste positieve effect gehad op de respons. Hiermee is de stabiliteit en de betrouwbaarheid van de onderzoeksresultaten aanzienlijk toegenomen. Een mogelijk neveneffect kan zijn dat er (kleine) trendbreuken plaatsvinden in de cijfers. Daar waar dit het geval kan zijn, wordt hier in het rapport op gewezen.

In de tweede plaats is dit rapport gebaseerd op gegevens uit het POA-project (Project Onderwijs-Arbeidsmarkt). Middels het POA-project wordt getracht inzicht te verwerven in de huidige en toekomstige arbeidsmarktsituatie van de verschillende beroepen en opleidingen over de hele breedte van de arbeidsmarkt. In hoofdstuk 5 van dit rapport wordt van gegevens uit het POA-project gebruik gemaakt.

Dit rapport is samengesteld door drs. P. van Eijs. Verder is aan dit rapport meegewerkt door M. Beenkens, drs. T. Huijgen en E. Soudant. 


\section{$2 \quad$ Na de MBO-opleiding}

$\mathrm{Na}$ het afronden van de opleiding staat de MBO-schoolverlater een aantal mogelijkheden ter beschikking. Hij of zij kan kiezen voor de arbeidsmarkt en al dan niet succesvol op zoek gaan naar een baan. Ook een vervolgopleiding behoort tot de mogelijkheden. Dit kan een MBO-opleiding zijn op een hoger niveau of via een andere leerweg. De hoger opgeleide MBO'er kan kiezen voor een HBO-opleiding. In dit hoofdstuk staat de maatschappelijke positie van de MBO'ers zo'n anderhalf jaar na afstuderen centraal.

\section{Werkloosheid loopt vooral bij BOL'ers wat op}

Kijkend naar de maatschappelijke positie van schoolverlaters, springt de werkloosheid het meest in het oog. Figuur 2.1 laat zien dat na de uitzonderlijke lage werkloosheid in de jaren 1999 en 2000, de werkloosheid onder MBO-schoolverlaters in 2001 en 2002 weer wat oploopt. In 2000 zat nog maar 1,8\% van de MBO'ers anderhalf jaar na afstuderen zonder werk, in 2002 is 3,3\% van de schoolverlaters die tot de beroepsbevolking gerekend kunnen worden werkloos. In historisch perspectief is dit nog altijd vrij laag.

Figuur 2.1

Werkloosheid onder MBO-schoolverlaters als percentage van de beroepsbevolking naar niveau en leerweg, 1998-2002

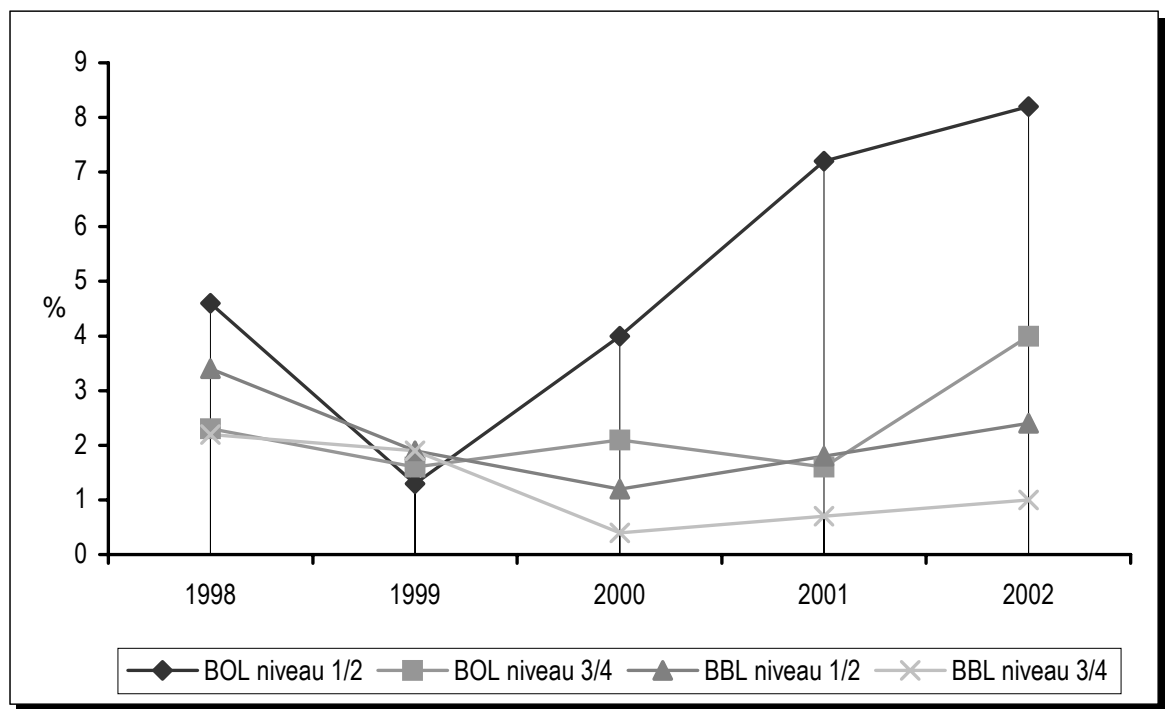

Bron: ROA (RUBS)

Figuur 2.1 laat zien dat schoolverlaters van de beroepsopleidende leerweg (BOL) vaker moeite ondervinden om werk te vinden. Zo was in $20004 \%$ van de BOL'ers niveau 1 en 2 werkloos. In 2002 is dit meer dan $8 \%$. Ook onder BOL'ers niveau 3 en 4 is de werkloosheid sinds 2000 verdubbeld tot $4 \%$. Onder schoolverlaters van de 
beroepsbegeleidende leerweg (BBL) is de werkloosheid in 2002 nog steeds uitzonderlijk laag.

\section{Bijna de helft van de BOL'ers studeert verder}

Figuur 2.2 toont de maatschappelijke positie van de MBO-schoolverlaters naar opleidingssector. Grofweg heeft zo'n $60 \%$ betaald werk en kiest ruim 35\% voor een vervolgopleiding. Uit de figuur blijkt dat BOL'ers veel vaker voor een vervolgopleiding kiezen dan BBL'ers. Over het algemeen kiest bijna de helft van de BOL'ers ervoor om verder te studeren. Zij geven aan student te zijn of een BBL-traject te volgen. Dit is aanzienlijk meer dan in de voorafgaande jaren. Dit heeft mogelijk deels te maken met de onzekere economische situatie waardoor schoolverlaters de zoektocht naar een baan nog wat willen uitstellen. Een belangrijke uitzondering is de sector BOL niveau 3 en 4 gezondheidszorg. Bijna $30 \%$ van de schoolverlaters kiest voor een vervolgopleiding, terwijl maar liefst bijna $70 \%$ heeft gekozen voor een betaalde baan. De aanzuigende werking van de arbeidsmarkt, die gekenmerkt wordt door een groot tekort aan zorgopgeleiden, speelt hierbij zeker een rol.

Figuur 2.2

De maatschappelijke positie van schoolverlaters in procenten naar opleidingssector, 2002

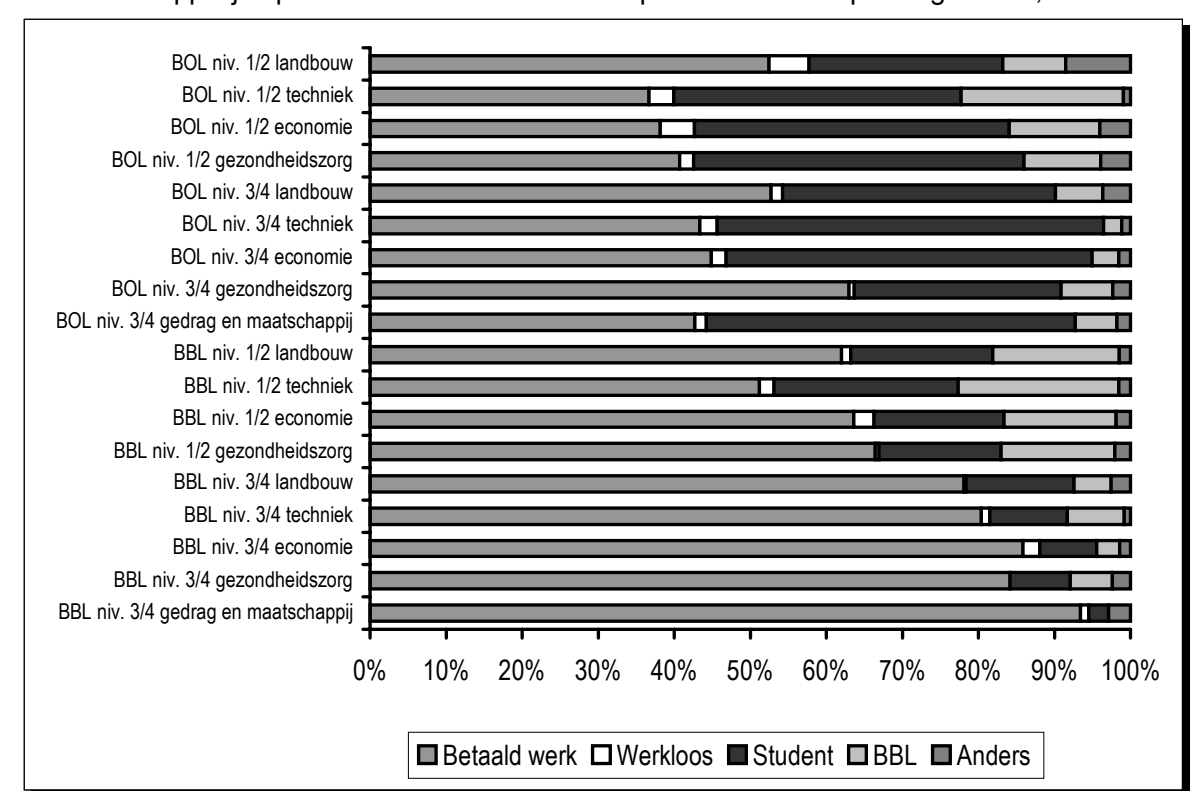

Bron: ROA (RUBS)

Schoolverlaters van de beroepsbegeleidende leerweg kiezen vaak voor de arbeidsmarkt. Dit wijst erop dat BBL'ers over het algemeen meer over op de praktijk gerichte vaardigheden beschikken en meer gericht zijn op werk. Ook de band met het leerbedrijf kan hierbij een rol spelen. Over het algemeen kiest meer dan $80 \%$ van de BBL'ers voor de arbeidsmarkt. Met name onder BBL'ers niveau 3 en 4 is de animo om verder te studeren gering. Zo kiest minder dan $8 \%$ van de economisch opgeleide BBL'ers niveau 3 en 4 voor een vervolgopleiding. Ter vergelijking: voor de sector 
BOL niveau 3 en 4 economie geeft bijna 50 procent aan student te zijn of een BBLtraject te volgen. Van de technisch opgeleiden kiest $11 \%$ van de BBL'ers en $52 \%$ van de BOL'ers voor een vervolgopleiding.

Tabel 2.1 biedt inzicht in de verschillen in de maatschappelijke positie naar geslacht en etniciteit. De tabel laat zien dat er in 2002 nauwelijks verschillen zijn tussen mannen en vrouwen. Allochtonen kiezen wat vaker voor een vervolgopleiding. Ruim $40 \%$ van de allochtonen kiest ervoor om verder te studeren. Onder de autochtone schoolverlaters is dit ruim $35 \%$. De werkloosheid onder allochtonen is aanzienlijk hoger dan onder autochtonen. De verschillen tussen allochtonen en autochtonen kunnen voor een belangrijk deel worden verklaard door verschillen in de opleidingsachtergrond. Zo kiezen allochtonen relatief vaak voor een BOL-opleiding op niveau 1 of 2 .

Tabel 2.1

De arbeidsmarktpositie van MBO-schoolverlaters naar geslacht en etniciteit, 2002, percentages

\begin{tabular}{lrrrrr}
\hline Positie & Man & Vrouw & Allochtoon & Autochtoon & Totaal \\
\hline Betaald werk & 60 & 61 & 50 & 60 & 60 \\
Werkloos & 2 & 2 & 6 & 2 & 2 \\
Student / BBL & 37 & 35 & 32 & 36 & 36 \\
Anders & 2 & 3 & 3 & & \\
\hline Bron: $R O A$ (RUBS) & & & & &
\end{tabular}

Bron: ROA (RUBS)

\section{BBL'ers hebben voortvarender start op arbeidsmarkt dan BOL'ers}

We hebben reeds gezien dat de werkloosheid onder MBO-schoolverlaters weer wat oploopt. Met name allochtonen en schoolverlaters van BOL-opleidingen op niveau 1 en 2 ondervinden na het behalen van het diploma meer moeite om werk te vinden. Daarnaast is het zinvol te kijken naar de wijze waarop de starter zijn weg vindt op de arbeidsmarkt. Is er sprake van een moeizame start? Of is de overgang van school naar werk gladjes verlopen?

Een indicator voor deze startersproblematiek is de intredewerkloosheid. Slechts $3 \%$ van de MBO-schoolverlaters die zo'n anderhalf jaar geleden het diploma heeft gehaald is in totaal langer dan drie maanden werkloos geweest. Hiermee is de intredewerkloosheid zelfs lager dan voor het cohort dat een jaar eerder de opleiding heeft afgerond. Dit is opvallend gezien de oplopende werkloosheid. Het illustreert het gunstig gesternte waaronder deze lichting in 2001 toetrad tot de arbeidsmarkt. $\mathrm{Nu}$ het economisch minder gaat, verliezen ook MBO'ers vaker hun baan. Figuur 2.3 toont de verschillen in de intredewerkloosheid naar opleidingssector. Met name BOL'ers met een diploma op niveau 1 en 2 springen opnieuw in het oog. In de sectoren BOL niveau 1 en 2 landbouw en gezondheidszorg is de intredewerkloosheid het hoogst. Meer dan 6\% van de schoolverlaters is langer dan drie maanden werkloos geweest. BBL'ers ondervinden veel minder problemen. De werkervaring opgedaan tijdens de opleiding biedt de BBL'er de mogelijkheid relatief snel een baan te verwerven bij de huidige of de nieuwe werkgever. Onder schoolverlaters met een diploma op 
niveau 3 en 4 is de intredewerkloosheid over het algemeen laag. Vermeldenswaard is echter de hoge intredewerkloosheid (meer dan 5\%) in de sectoren BOL en BBL gedrag en maatschappij niveau 3 en 4.

\section{Figuur 2.3}

Intredewerkloosheid onder MBO'ers van vier maanden of langer in procenten naar opleidingssector, 2002

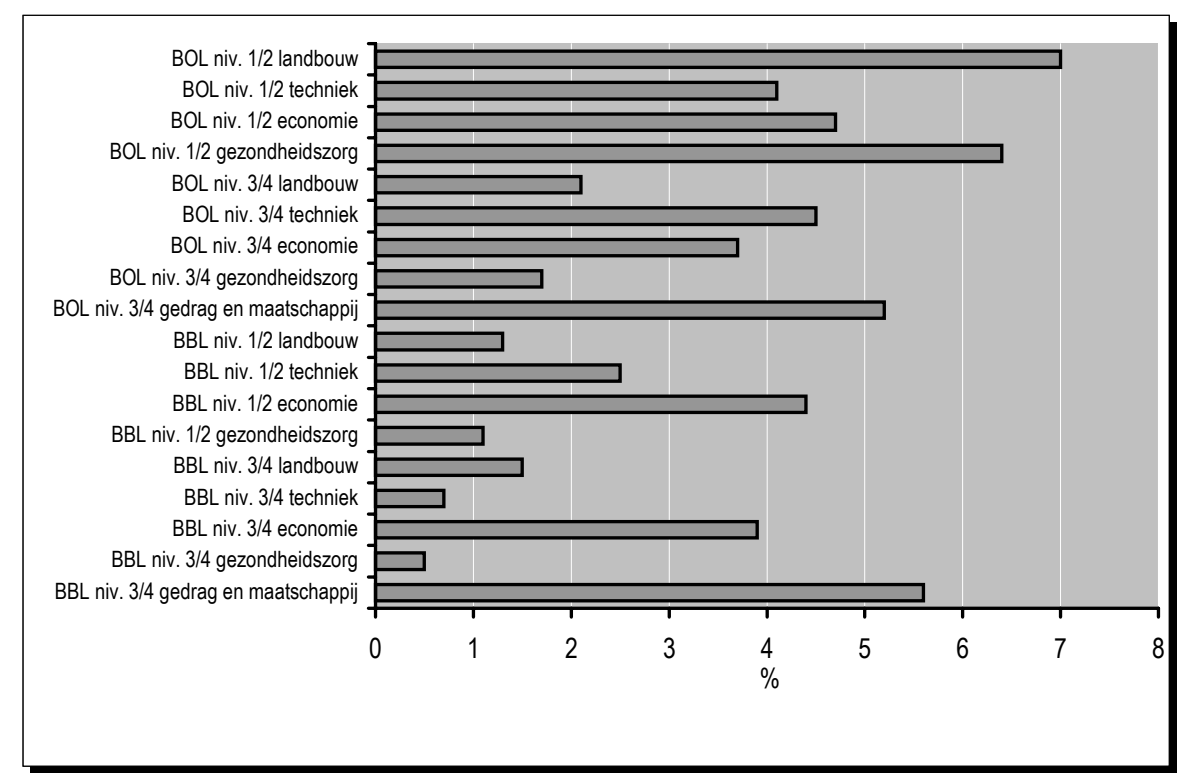

Bron: ROA (RUBS)

Een nauw verwante indicator voor de startersproblematiek is het percentage schoolverlaters dat werkloos is geweest gedurende de eerste anderhalf jaar van de beroepsloopbaan. Figuur 2.4 geeft hiervan een overzicht. De figuur illustreert de economische neergang die zich in 2002 begint af te tekenen. Daar waar, zoals uit figuur 2.3 bleek, veel MBO'ers relatief snel een baan konden vinden, blijkt bijna $10 \%$ van de MBO-schoolverlaters wel eens werkloos te zijn geweest in de eerste anderhalf jaar van hun loopbaan. Dit is een sterke aanwijzing dat MBO'ers het het afgelopen jaar moeilijker hebben gekregen. Verder laten figuur 2.3 en 2.4 een vergelijkbaar beeld zien. Opnieuw zijn het de BOL-opleidingen niveau 1 en 2 die er in negatieve zin uitspringen. Bijna een kwart van de BOL'ers niveau 1 en 2 landbouw en gezondheidszorg is wel eens werkloos geweest. Maar ook BOL'ers uit andere sectoren - ook van niveau 3 en 4 - worden relatief vaker met werkloosheid geconfronteerd. Een schril contrast met bijvoorbeeld de sector BBL niveau 3 en 4 gezondheidszorg. De werkloosheid onder schoolverlaters van deze sector is te verwaarlozen.

\section{BBL'ers kiezen vaker voor een verwante opleiding}

We richten ons vizier nu op de verder lerende schoolverlaters. Het Nederlandse onderwijssysteem biedt de student een grote variëteit aan leerroutes. Vanuit het onderwijs is het interessant om na te gaan in hoeverre MBO-schoolverlaters kiezen 
voor een verwante opleiding. Kiest men voor een opleiding binnen de beroepskolom of waaiert men uit naar een breed scala aan opleidingen? Gemiddeld zo'n driekwart van de verder lerende MBO'ers kiest voor een verwante opleiding. Figuur 2.5 laat zien dat er tussen de opleidingen echter aanzienlijke verschillen zijn. Technisch opgeleiden kiezen relatief vaak voor een verwante opleiding. BOL'ers gedrag en maatschappij niveau 3 en 4 kiezen het vaakst voor een opleiding die niet in het verlengde van hun afgesloten opleiding ligt. Slechts $55 \%$ kiest voor een verwante opleiding. BBL'ers lijken wat vaker voor een verwante opleiding te kiezen dan BOL'ers. Dit zou verband kunnen houden met de wat meer praktische en beroepsgerichte oriëntatie van BBL-opleidingen. De nadruk op beroepsgerichte vaardigheden maakt de overstap naar een niet-verwante opleiding wat moeilijker. Mogelijk speelt ook de relatie met het leerbedrijf een rol. BBL'ers blijven wellicht bij het leerbedrijf en kiezen in overleg met het leerbedrijf een vervolgopleiding. Overigens dient wel opgemerkt te worden dat, zoals we reeds eerder hebben gezien, BBL'ers veel minder vaak kiezen voor een vervolgopleiding dan BOL'ers.

Figuur 2.4

Percentage MBO-schoolverlaters dat werkloos is geweest naar opleidingssector, 2002

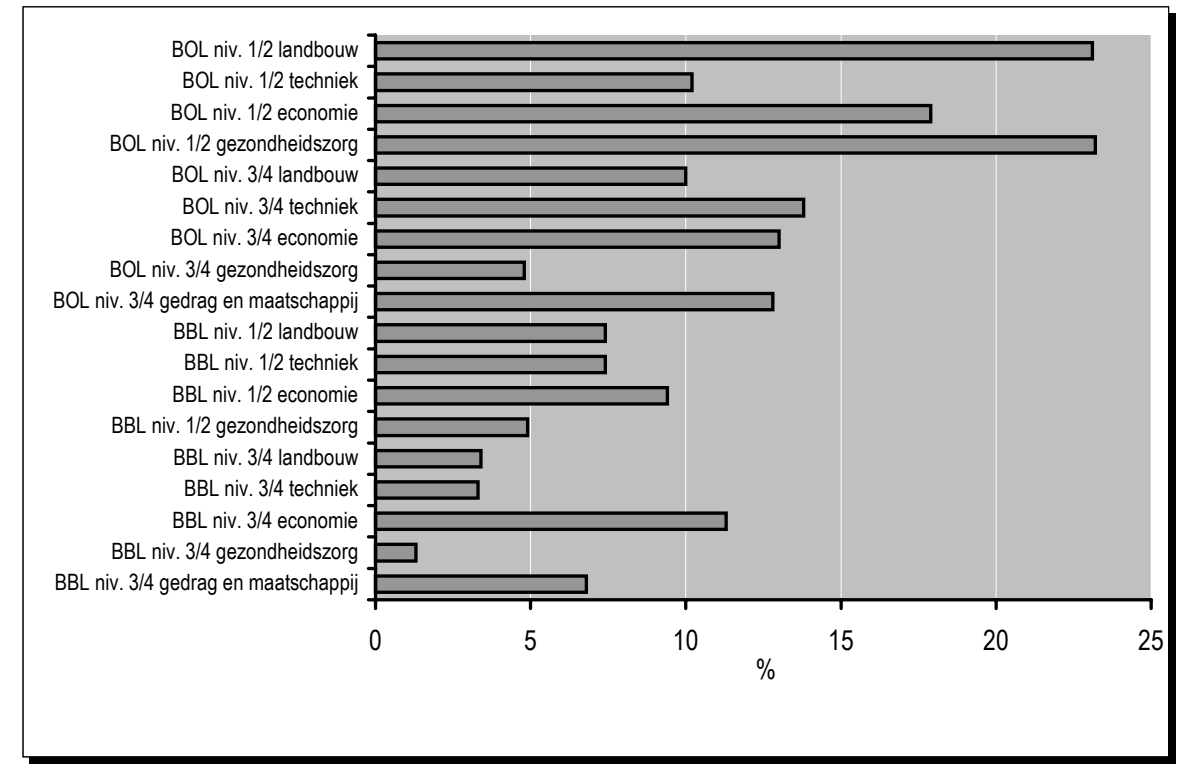

Bron: ROA (RUBS)

\section{$B O L$ 'ers kiezen vaker voor het $H B O$}

Schoolverlaters van opleidingen op niveau 4 hebben de mogelijkheid voor het hoger beroepsonderwijs te kiezen. In figuur 2.6 wordt de doorstroom van verder lerende MBO'ers naar het HBO in kaart gebracht. BOL'ers blijken veel vaker voor een HBOopleiding te kiezen dan BBL'ers. Het ligt voor de hand dat aan dit patroon dezelfde oorzaken ten grondslag liggen als aan het feit dat BBL'ers vaker voor een verwante opleiding kiezen. Het beroepsgerichte, meer praktische karakter van BBL-opleidingen en de band met het leerbedrijf maken verwante opleidingen op MBO-niveau wellicht 
veel aantrekkelijker dan een HBO-opleiding. Mogelijk dat door het uitbreiden van de mogelijkheden om een duale opleiding op HBO-niveau te volgen, de doorstroom vanuit BBL-opleidingen naar het HBO bevorderd zou kunnen worden.

\section{Figuur 2.5}

Doorstroom van verder lerende MBO'ers naar verwante opleidingen in procenten naar opleidingssector, 2002*

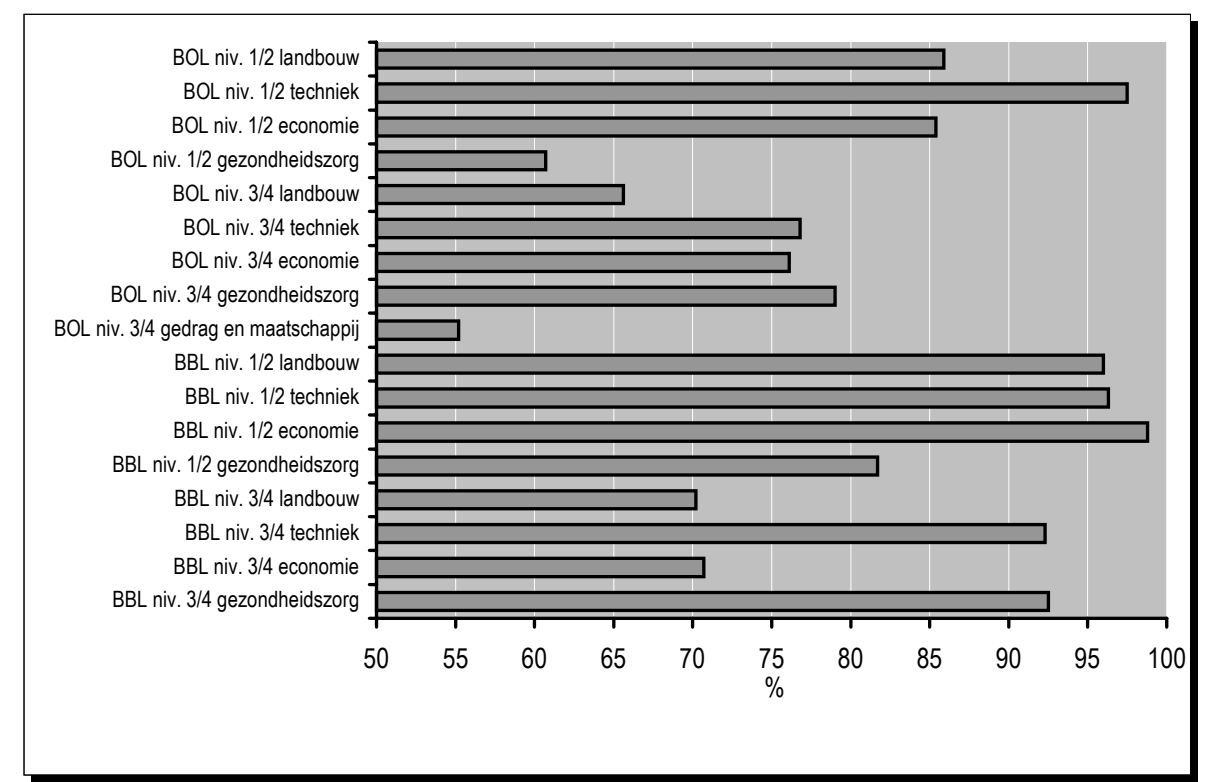

* Het aantal verder lerenden met als achtergrond een opleiding in de sector BBL niveau 3 en 4 gedrag en maatschappij is te klein om betrouwbare uitspraken te kunnen doen.

Bron: ROA (RUBS)

\section{Figuur 2.6}

Doorstroom van verder lerende MBO'ers naar het HBO in procenten naar opleidingssector, 2002*

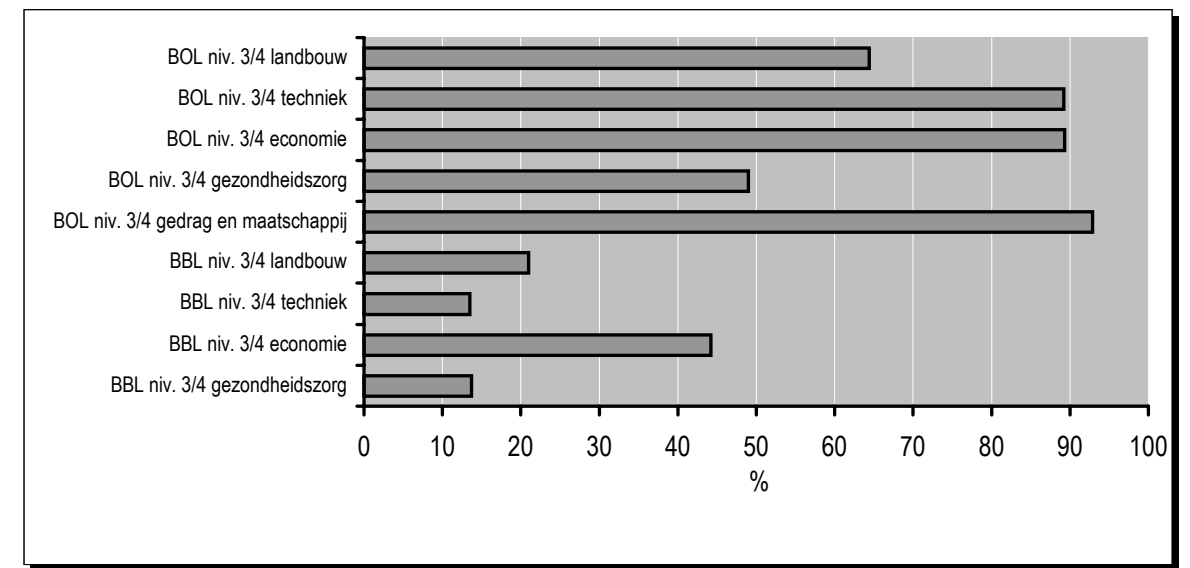

* Het aantal verder lerenden met als achtergrond een opleiding in de sector BBL niveau 3 en 4 gedrag en maatschappij is te klein om betrouwbare uitspraken te kunnen doen. Bron: ROA (RUBS) 
Meer dan $90 \%$ van de schoolverlaters van een opleiding in de sector BOL niveau 3 en 4 gedrag en maatschappij die voor een vervolgopleiding kiezen, kiest voor het HBO. Ook BOL'ers niveau 3 en 4 met een technische of een economische achtergrond kiezen vaak voor een HBO-opleiding. De agrarisch opgeleiden en vooral de zorgopgeleiden kiezen veel minder vaak voor een HBO-opleiding. Bij de zorgopgeleiden is dit zelfs minder dan $50 \%$. Vanuit het BBL stromen met name economisch opgeleiden door naar het HBO (bijna 45\%). Vanuit de technische en de zorgopleidingen stroomt slechts ruim $10 \%$ van de degenen die verder leren door naar het $\mathrm{HBO}$. 



\section{MBO'ers aan het werk}

In dit hoofdstuk richten we ons vizier op de werkende MBO'er. In het vorige hoofdstuk hebben we gezien dat ongeveer $60 \%$ van de schoolverlaters zo'n anderhalf jaar na afstuderen betaald werk heeft. De vraag rijst hoe goed de MBO'er rendeert op de arbeidsmarkt. We bekijken daartoe twee aspecten: de werkzekerheid en de beloning. Beide aspecten vormen bovendien belangrijke indicatoren voor de arbeidsmarktpositie van MBO'ers. Vervolgens gaat dit hoofdstuk dieper in op de inhoudelijke aansluiting tussen opleiding en werk. Deze aansluiting heeft twee dimensies: de aansluiting naar niveau en de aansluiting naar richting.

Figuur 3.1

MBO-schoolverlaters met een tijdelijk arbeidscontract in procenten, 1998-2002

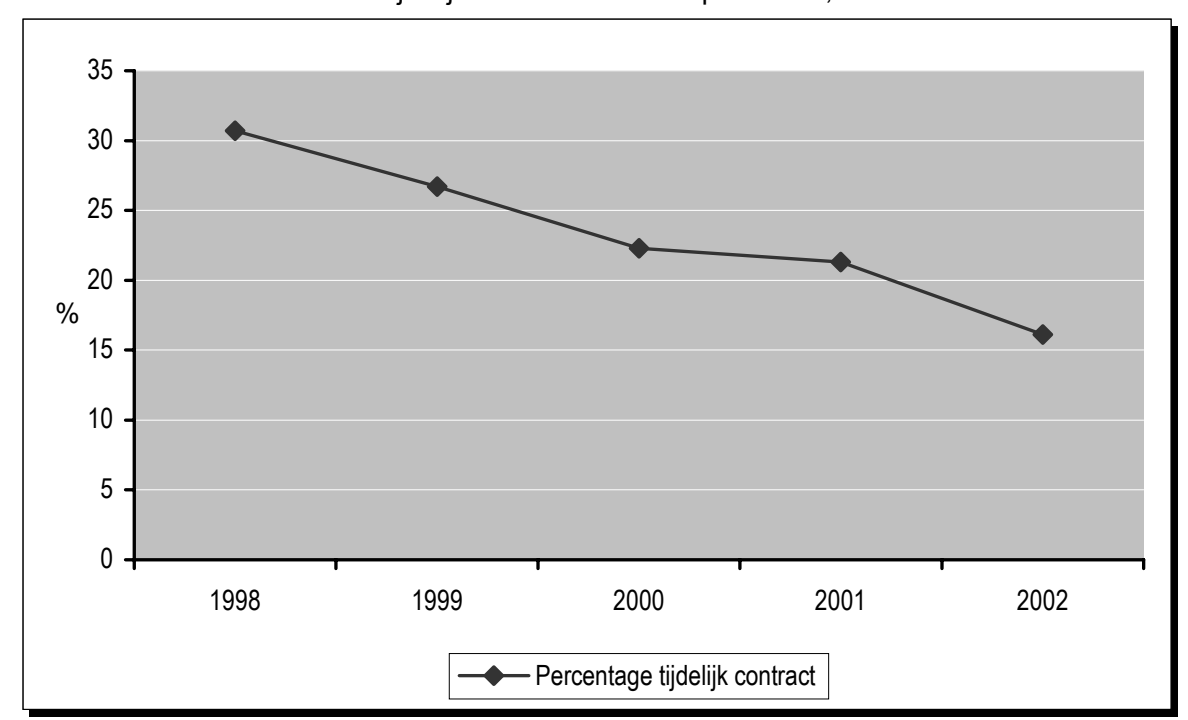

Bron: ROA (RUBS)

\section{Werkzekerheid aanzienlijk toegenomen}

De flexibilisering van de arbeidsmarkt was een aantal jaren geleden een hot item. Flexibilisering werd gezien als een belangrijk middel om de slagvaardigheid van bedrijven te bevorderen en de kansen van werknemers op de arbeidsmarkt te vergroten. Het tekort aan personeel van de laatste jaren heeft deze discussie wat naar de achtergrond gedrongen. Als gevolg hiervan hebben bedrijven er onder meer steeds vaker voor gekozen werknemers aan zich te binden. Figuur 3.1 illustreert dit. De figuur laat zien dat de werkzekerheid voor MBO-schoolverlaters de laatste jaren is toegenomen. Steeds vaker weten MBO'ers een vaste aanstelling te verwerven. In 1998 had ruim 30\% van de MBO-schoolverlaters een tijdelijke aanstelling. In 2002 is dit percentage bijna gehalveerd tot $16 \%$. 


\section{Economen hebben vaak een tijdelijke aanstelling}

Op specifieke segmenten van de arbeidsmarkt is er sprake van een grote werkzekerheid, terwijl de toekomst van MBO'ers op andere delen van de arbeidsmarkt veel onzekerder is. De verschillen tussen de opleidingssectoren zijn groot. Figuur 3.2 laat deze verschillen binnen het $\mathrm{MBO}$ zien. Het meest in het oog springt het verschil tussen BOL en BBL. BOL'ers werken veel vaker met een tijdelijk arbeidscontract dan BBL'ers. Blijkbaar kijken werkgevers bij BOL'ers wat vaker de kat uit de boom. De werkervaring die BBL'ers tijdens hun opleiding hebben opgedaan, wordt door de werkgever beloond met een grotere werkzekerheid. Werkgevers zullen wellicht zelfs als leerbedrijf al ervaring met de betrokkene hebben opgedaan. Verder lijken schoolverlaters met een diploma op niveau 1 of 2 vaker een tijdelijke aanstelling te hebben dan schoolverlaters met een diploma op niveau 3 of 4 . Ook bij de lager opgeleiden zijn de werkgevers dus wat voorzichtiger. Ten slotte blijken economisch opgeleiden vaker een tijdelijk contract voorgelegd te krijgen dan schoolverlaters uit andere opleidingssectoren. Het percentage tijdelijke contracten is het hoogst voor de sector BOL niveau 1 en 2 economie: ruim 30\%. De laagste percentages zijn te vinden bij de BBL-opleidingen op niveau 3 en 4 . Maar ook voor de sector BOL niveau 3 en 4 gezondheidszorg is het percentage tijdelijke aanstellingen opvallend laag.

Figuur 3.2

MBO-schoolverlaters met een tijdelijk arbeidscontract in procenten naar opleidingssector, 2002

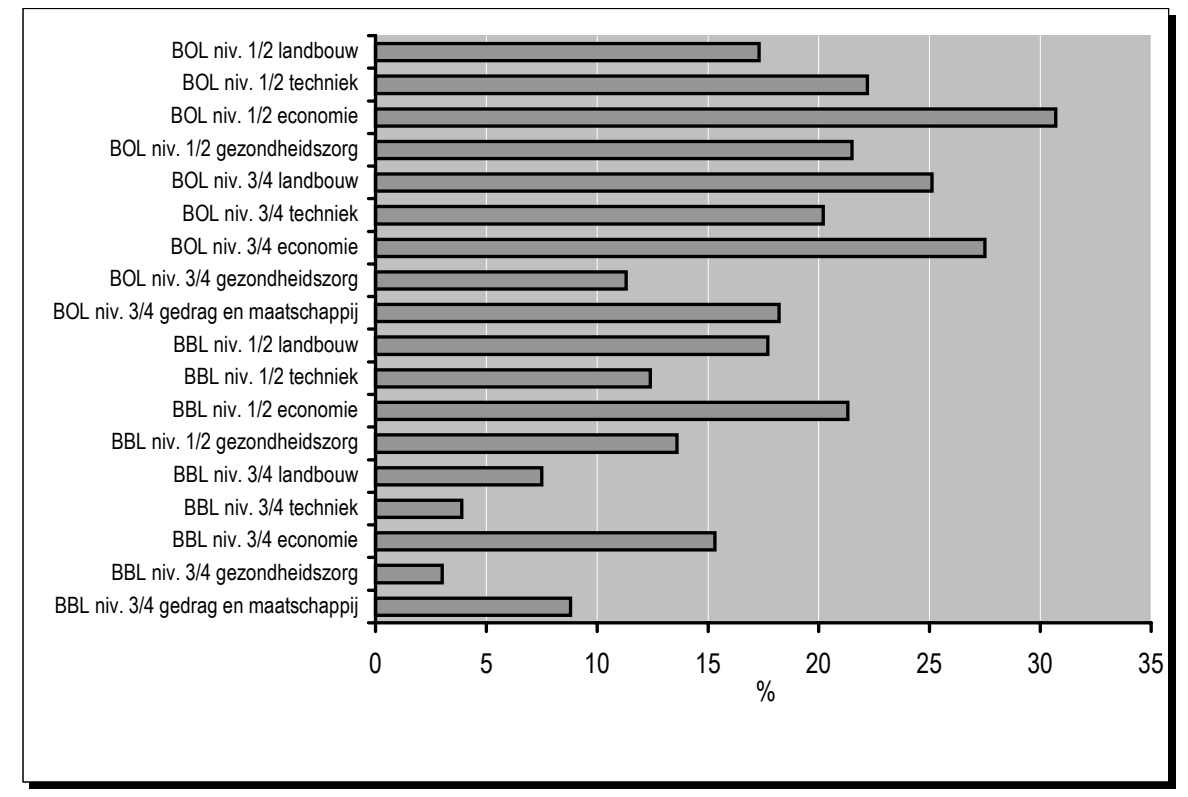

Bron: ROA (RUBS)

\section{Lonen in 2002 iets gedaald}

Een belangrijke indicator voor de arbeidsmarktpositie van opleidingen vormt de beloning. De beloning geeft immers een directe indicatie van de waarde van de verworven kwalificaties op de arbeidsmarkt. Figuur 3.3 laat de loonontwikkeling 
gedurende de afgelopen vijf jaar zien. Onder invloed van de krapte op de arbeidsmarkt en de oplopende inflatie stegen de lonen van MBO-schoolverlaters de afgelopen jaren sterk. In 2001 bleken de MBO-schoolverlaters gemiddeld zelfs zo'n 10\% meer te verdienen dan de lichting die een jaar eerder was afgestudeerd. De figuur laat zien dat aan deze loonstijging in 2002 een einde is gekomen. Vergeleken met 2001 zijn de lonen zelfs met bijna $4 \%$ gedaald. ${ }^{2}$ Naast de wat oplopende werkloosheid en de groeiende flexibele arbeidsmarkt is dit een opnieuw een indicatie voor het feit dat er arbeidsmarkt voor MBO'ers in 2002 wat minder rooskleurig is dan de jaren daarvoor.

Figuur 3.3

Ontwikkeling mediaan bruto uurloon MBO-schoolverlaters naar leerweg en niveau in euro's, 1998-2002

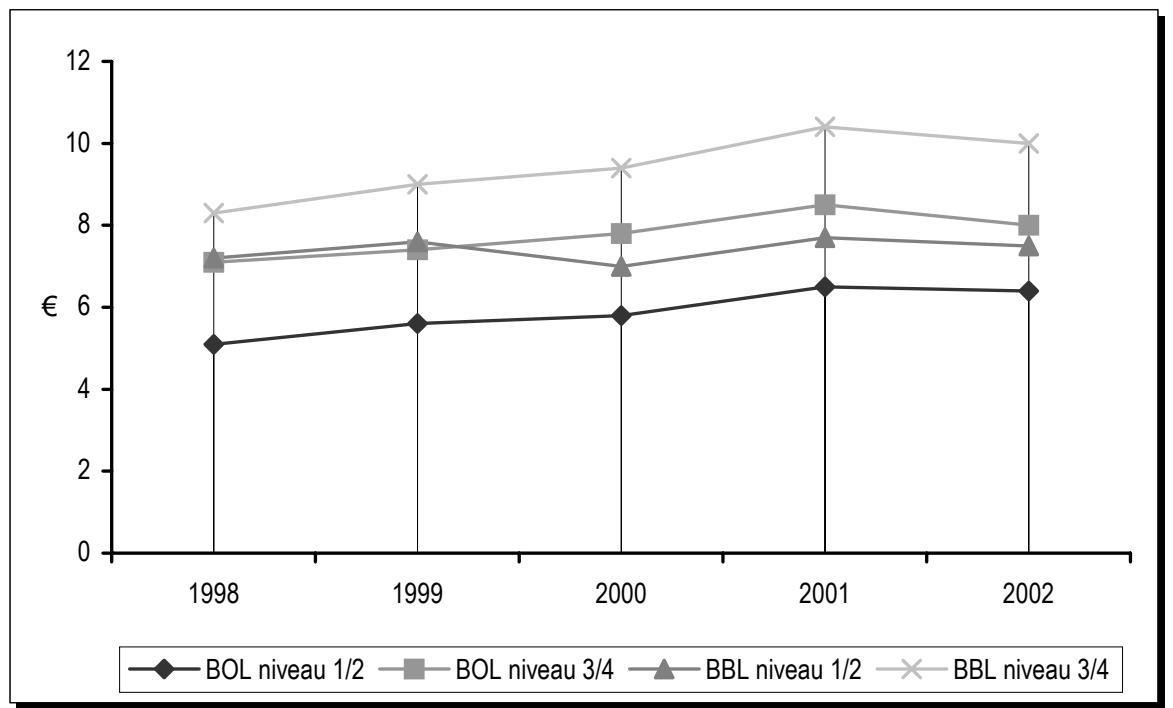

Bron: ROA (RUBS)

Opvallend is het verschil in beloning tussen BOL'ers en BBL'ers. BBL'ers verdienen aanzienlijk meer dan BOL'ers. We hebben al eerder gezien dat de werkgever de werkervaring die BBL'ers tijdens hun opleiding hebben opgedaan belonen met een grotere werkzekerheid. Deze waardering komt dus ook in de beloning tot uiting. Als gevolg hiervan is de beloning voor schoolverlaters van BBL-opleidingen niveau 3 en 4 het hoogst. BOL'ers niveau 1 en 2 verdienen verreweg het minst. Overigens laat onderzoek zien dat BOL'ers de achterstand in de beloning op de BBL'ers snel inhalen. Daarnaast dient hierbij opgemerkt te worden dat er bij loonverschillen ten dele sprake kan zijn van een leeftijdseffect. Zo zijn schoolverlaters van niveau 3 en 4 logischerwijs gemiddeld wat ouder dan schoolverlaters van niveau 1 en 2.

2. Mogelijk wordt een gedeelte van het verschil tussen 2001 en 2002 veroorzaakt door de invoering van de euro die vooral in 2001 tot enige vertekening in de cijfers kan hebben geleid. 
Figuur 3.3 liet zien dat BBL'ers zo'n anderhalf jaar na afstuderen beter beloond worden dan BOL'ers. Echter, niet alleen de leerweg doet ertoe; de beloning verschilt ook per sector. Figuur 3.4 illustreert dit. Ongeacht de leerweg en het niveau worden technisch en zorgopgeleiden beter beloond dan hun collega's van andere opleidingssectoren. Ook de sector gedrag en maatschappij springt erg in het oog. Zo verdienen schoolverlaters uit de opleidingssector BBL niveau 3 en 4 gedrag en maatschappij met een bruto uurloon van ruim $€ 11$ het meest. De beloning van BBL'ers niveau 3 en 4 economie blijft hier bijvoorbeeld meer dan $€ 3$ bij achter.

Figuur 3.4

Mediaan bruto uurloon MBO-schoolverlaters (exclusief nevenfuncties) naar opleidingssector in euro's, 2002

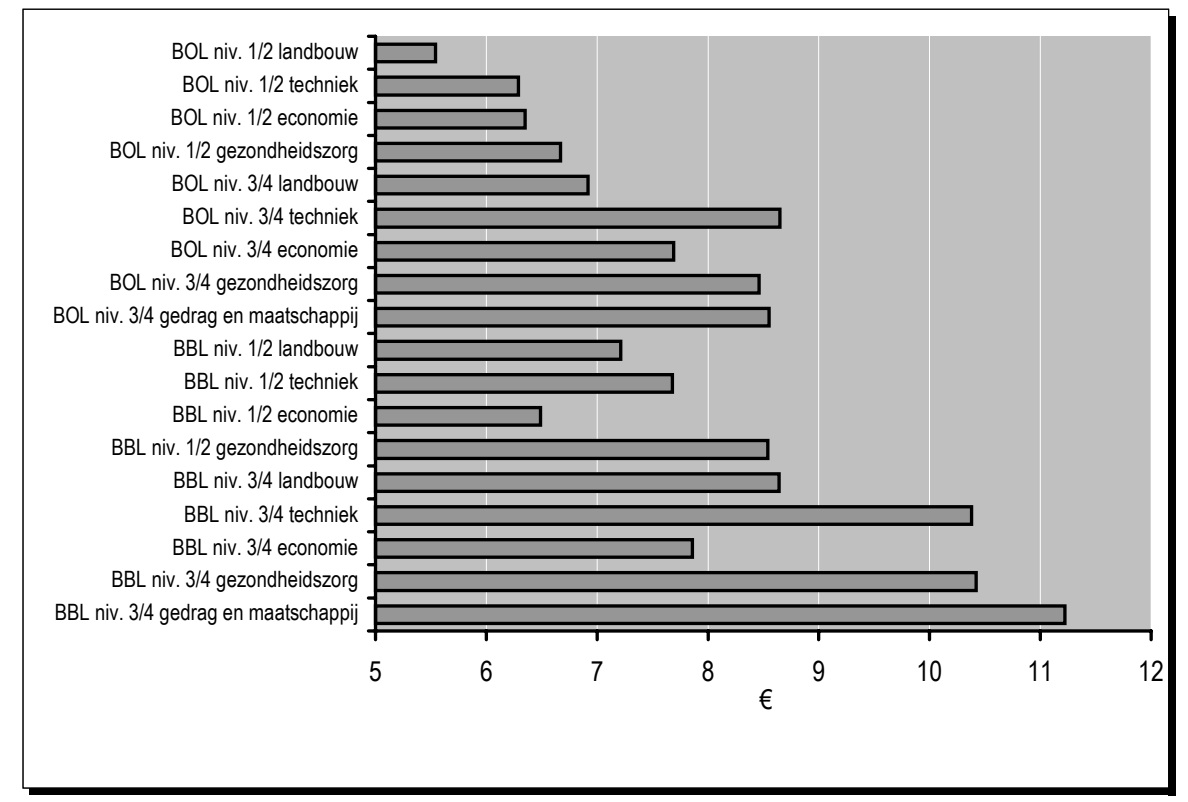

Bron: ROA (RUBS)

\section{Onderbenutting min of meer stabiel}

De mate waarin de in de opleiding verworven kwalificaties aansluiten bij de door de werkgever vereiste kwalificaties vormt een belangrijke indicator voor de arbeidsmarktpositie van schoolverlaters en de kwaliteit van de aansluiting tussen onderwijs en arbeidsmarkt. Aansluitingsproblemen op de arbeidsmarkt voor schoolverlaters manifesteren zich bijvoorbeeld vaak in de noodzaak om een baan onder hun niveau te accepteren. Men spreekt dan wel van onderbenutting van iemands kwalificaties. $\mathrm{Er}$ is sprake van onderbenutting wanneer het door de werkgever vereiste opleidingsniveau lager is dan het verworven opleidingsniveau. Figuur 3.5 toont het belang van onderbenutting op de arbeidsmarkt voor MBO-schoolverlaters gedurende de afgelopen vijf jaar. De figuur laat zien dat het percentage MBO-schoolverlaters dat zo'n anderhalf jaar na afstuderen beneden zijn of haar niveau werkt geen duidelijke trend 
vertoont. Rond de 35 tot 40 procent van de MBO'ers is werkzaam in banen waarvoor de werkgever een lagere opleiding vereist dan de schoolverlater heeft afgerond.

Figuur 3.5

Onderbenutting bij MBO-schoolverlaters in procenten, 1998-2002

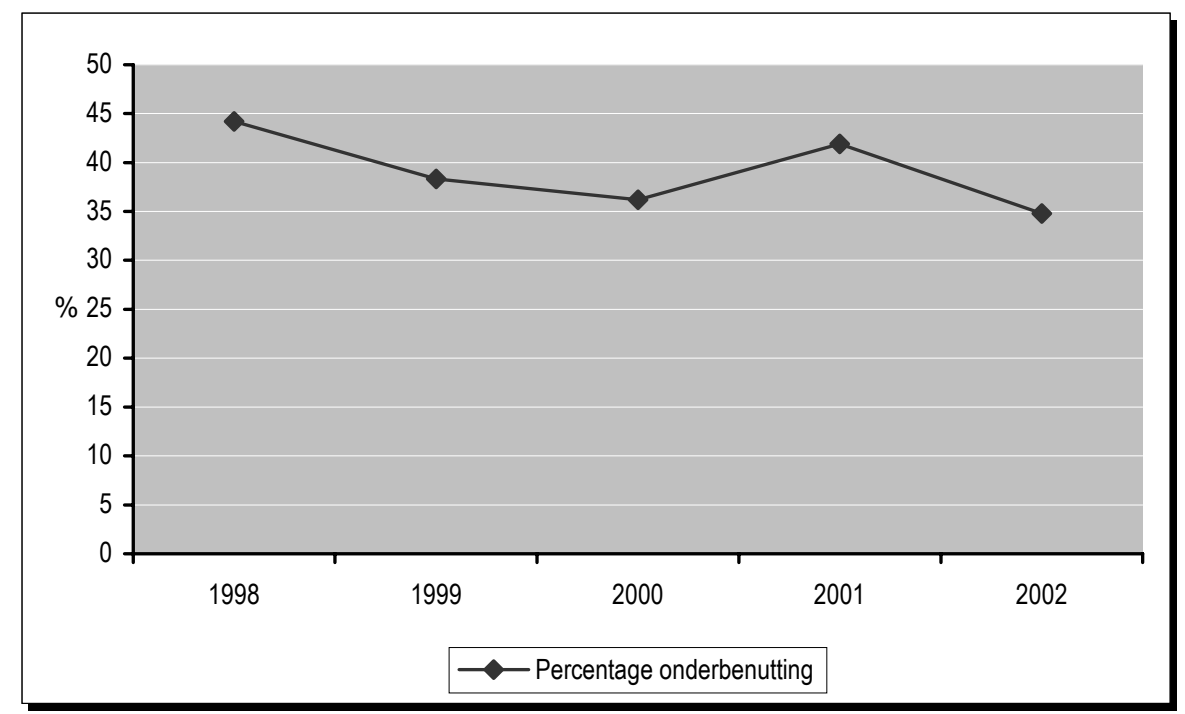

Bron: ROA (RUBS)

Figuur 3.6

Onderbenutting bij MBO-schoolverlaters in procenten naar opleidingssector, 2002

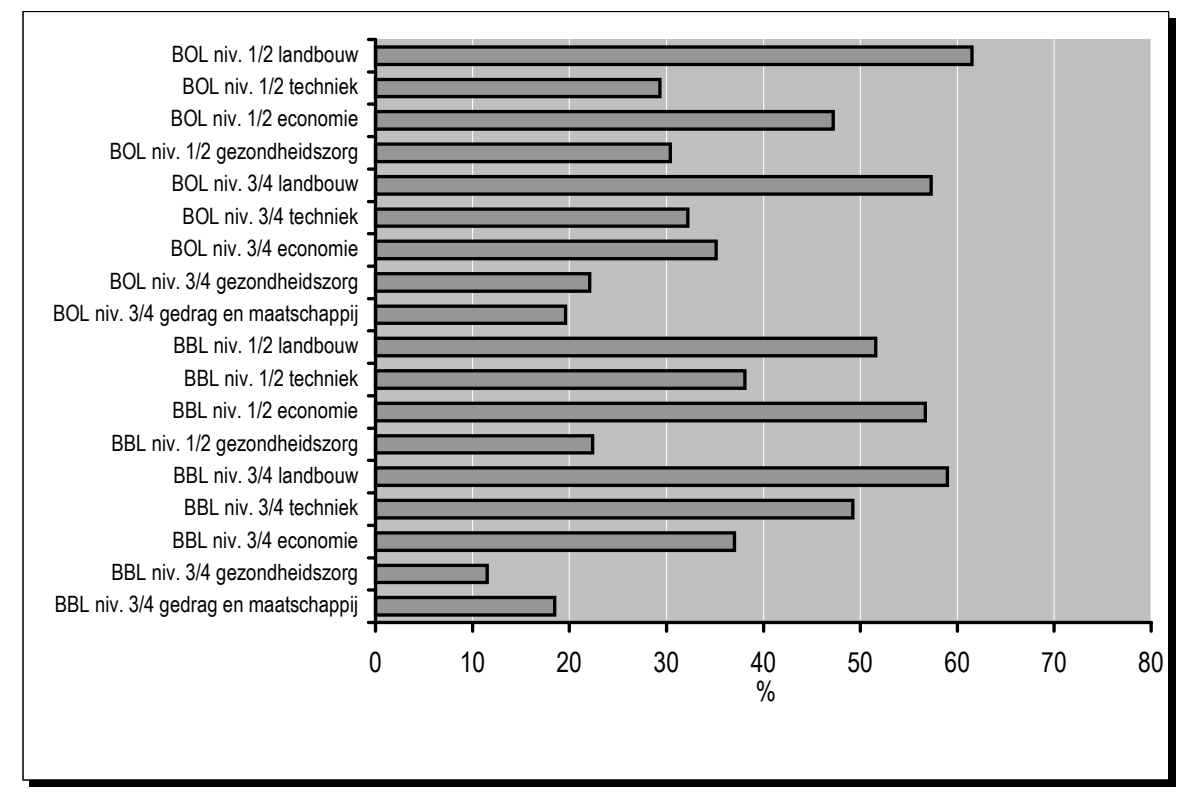

Bron: ROA (RUBS) 


\section{Zorgopgeleiden vaak op eigen niveau werkzaam}

Figuur 3.6 geeft inzicht in het verschijnsel onderbenutting naar opleidingssector. De figuur laat een sterk wisselend beeld zien. MBO'ers met een hoogste opleiding op niveau 1 of 2 werken relatief vaak onder hun niveau vergeleken met schoolverlaters die een opleiding op niveau 3 of 4 hebben afgerond. Verder lijkt ook de inhoud van de opleiding een rol te spelen. Met name de schoolverlaters van de landbouwopleidingen en in iets mindere mate economisch opgeleiden hebben relatief vaak een baan waarvoor de werkgever niet het eigen opleidingsniveau als minimale eis heeft gesteld. Ongeveer de helft van zowel de BOL'ers als de BBL'ers niveau 1 en 2 met een agrarische of een economische opleidingsachtergrond werkt beneden zijn of haar niveau. De onderbenutting is bij de opleidingssector BOL niveau 1 en 2 landbouw met bijna $62 \%$ het hoogst. Zorgopgeleiden komen daarentegen vaak in een baan op hun eigen niveau terecht. Zo is slechts $11 \%$ van de BBL'ers niveau 3 en 4 gezondheidszorg beneden zijn of haar niveau werkzaam.

Figuur 3.7

Werken buiten de vakrichting door MBO-schoolverlaters in procenten naar opleidingssector, 2002

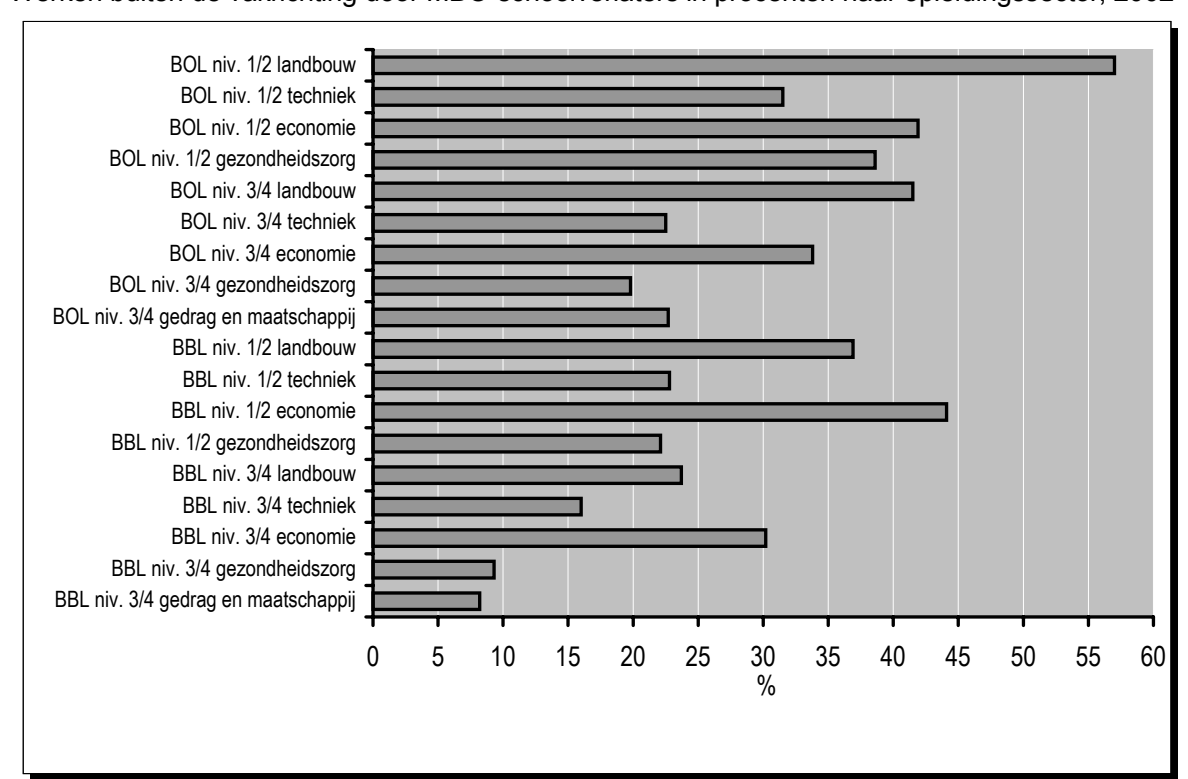

Bron: ROA (RUBS)

\section{Agrarisch en economisch opgeleiden werken vaak buiten eigen richting}

Ook het al dan niet kunnen toepassen van de in de opleiding verworven kwalificaties is een belangrijke maatstaf voor de kwaliteit van het werk en van de arbeidsmarktpositie. De tweede dimensie van de aansluitingsproblematiek tussen opleiding en beroepspraktijk wordt daarom gevormd door de vraag in hoeverre de baan aansluit bij de opleidingsrichting. Ruim een kwart van de MBO-schoolverlaters geeft aan in 2002 een baan te hebben waarvoor de werkgever een andere of geen specifieke opleidingsrichting vereist. Figuur 3.7 laat zien dat voor de agrarisch en de econo- 
misch opgeleiden de aansluiting tussen opleiding en beroepspraktijk opnieuw minder goed is dan voor de MBO'ers met andere opleidingsachtergrond. De zorgopgeleiden, de schoolverlaters uit de sector gedrag en maatschappij en de hogere technisch opgeleiden komen daarentegen vaak in hun eigen richting terecht. Zo werkt meer dan $90 \%$ van de BBL'ers niveau 3 en 4 gezondheidszorg en gedrag en maatschappij in een baan waarvoor de werkgever de eigen of een verwante opleiding vereist. Het sterk beroepsspecifieke karakter van bijvoorbeeld de opleidingen in de gezondheidszorg zal hieraan mogelijk mede ten grondslag liggen.

Ten slotte is een kanttekening op zijn plaats. Bij de opleidingen op niveau 1 en 2 betekenen hoge percentages onderbenutting en een minder goede aansluiting naar richting veelal dat de schoolverlaters terechtkomen op de zogenaamde 'secundaire arbeidsmarkt' in banen waarvoor nauwelijks of geen scholing vereist is. Bij de opleidingen op niveau 3 en 4 kan het juist betekenen dat de zij breed inzetbaar zijn en vanuit een wat mindere startpositie mogelijk toch een goed carrièreperspectief hebben. Zeker voor schoolverlaters met een opleiding op niveau 3 en 4 betekent een minder goede aansluiting dus niet per definitie dat er sprake is van een zwakke arbeidsmarktpositie. 



\section{De MBO'er aan het woord}

In dit hoofdstuk komt de MBO-schoolverlater zelf aan het woord. Vanuit verschillende invalshoeken wordt de tevredenheid van de MBO-schoolverlater onder de loep genomen. In de eerste plaats wordt gekeken naar het oordeel van de MBO'er over de aansluiting tussen de afgeronde opleiding enerzijds en de beroepspraktijk of de vervolgopleiding anderzijds. In de tweede plaats wordt gekeken naar de (werk)satisfactie van de MBO'er. Is men tevreden met de huidige functie? Of is men op zoek naar een (andere) baan? De derde invalshoek wordt gevormd door de tevredenheid met de studiekeuze. Zou men, terugkijkend, opnieuw voor dezelfde opleiding hebben gekozen? Het zoekgedrag en de eventuele spijt over de studiekeuze worden in het bijzonder bekeken in relatie tot de aansluiting tussen opleiding en beroepspraktijk.

\section{Figuur 4.1}

Oordeel over de aansluiting tussen opleiding en beroepspraktijk in procenten naar opleidingssector, 2002 (oordeel 'voldoende' of 'goed')

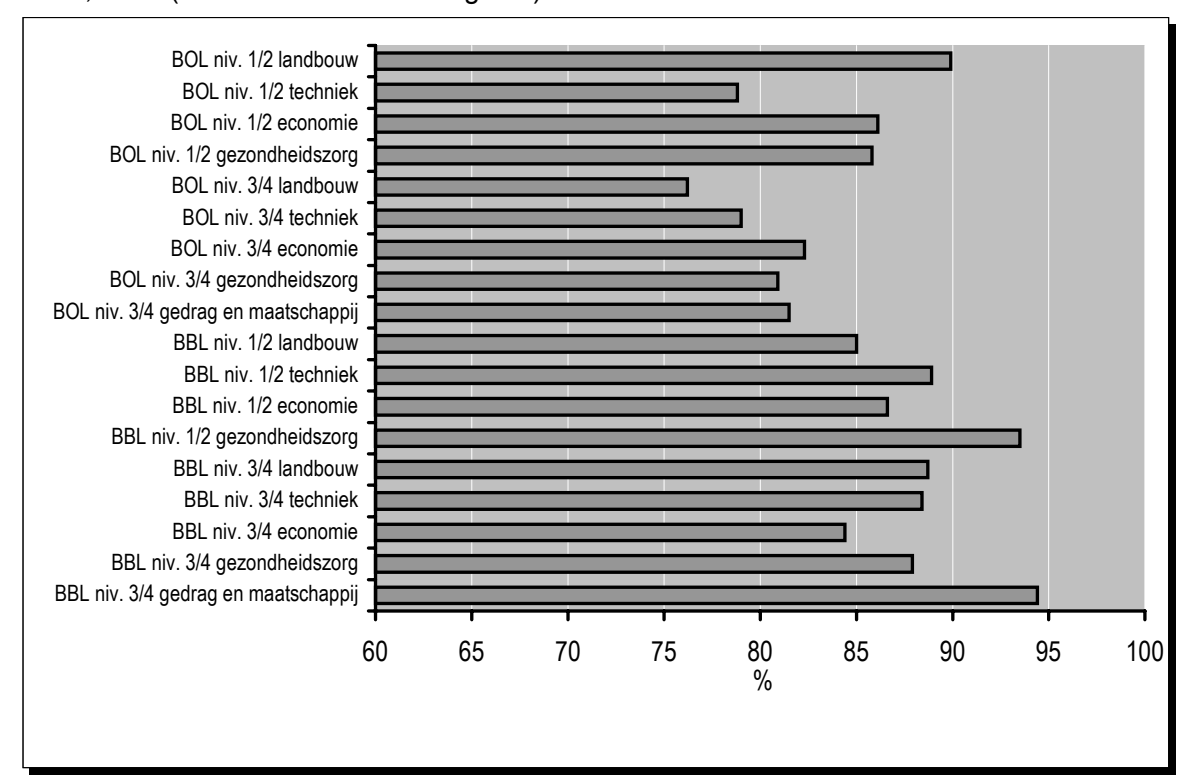

Bron: $R O A$ (RUBS)

Tevredenheid over aansluiting met beroep groot; BBL'ers het meest tevreden

De MBO-opleiding beoogt adequaat voor te bereiden op een eventuele vervolgopleiding en de beroepspraktijk. Hoe kijken de schoolverlaters hier tegenaan? Heeft de afgeronde MBO-opleiding voor een goede voorbereiding gezorgd? Of valt er het nodige aan te merken op de aansluiting tussen de afgeronde opleiding en de vervolgopleiding of beroepspraktijk. Figuur 4.1 laat zien in hoeverre de werkende MBO'er de aansluiting tussen opleiding en beroepspraktijk als 'voldoende' of 'goed' ervaart. Uit de figuur blijkt dat ongeveer $85 \%$ tevreden is over de aansluiting. Dit is 
verrassend hoog, gezien het feit dat zo'n $45 \%$ beneden zijn of haar niveau werkzaam is en ruim een kwart buiten de eigen richting, zoals hoofdstuk 3 liet zien. Een (objectief gezien) gebrekkige aansluiting betekent dus niet per definitie dat de schoolverlater dit als problematisch ervaart.

Ook binnen de sectoren is de tevredenheid groot. De percentages variëren van ruim $76 \%$ (BOL niveau 3 en 4 landbouw) tot ruim 94\% (BBL niveau 3 en 4 gedrag en maatschappij). BBL'ers lijken over het algemeen wat meer tevreden dan BOL'ers. Dit is niet verrassend gezien de sterke koppeling tussen theorie en praktijk gedurende de opleiding. Verder springen de technische opleidingen volgens de beroepsopleidende leerweg in het oog. De tevredenheid over de aansluiting van de schoolverlaters van deze opleidingen is relatief laag. Dit is opvallend gezien de over het algemeen (objectief gezien) goede aansluiting, zeker voor de opleidingen op niveau 3 en 4 . Wellicht speelt hier de perceptie een belangrijke rol. Schoolverlaters van beroepsspecifieke opleidingen kijken wellicht vanuit een ander (kritischer) perspectief naar de aansluiting dan schoolverlaters van 'bredere' opleidingen met een minder duidelijk beroepsbeeld.

\section{MBO'ers hebben behoefte aan meer aandacht voor de praktijk in de opleiding}

Aan de MBO'ers is een lijst met aspecten voorgelegd die van belang kunnen zijn voor het goed functioneren in de baan. Aan hen is gevraagd aan te geven in hoeverre er in de opleiding meer aandacht zou moeten worden geschonken aan deze aspecten. In tabel 4.1 wordt een overzicht gegeven in welke mate volgens de MBO-schoolverlaters die betaald werk hebben de aspecten onderbelicht blijven in de opleiding. In de tabel is aangegeven hoeveel procent van de schoolverlaters vindt dat aan het betreffende aspect meer aandacht zou moeten worden geschonken. Uit de tabel blijkt dat vooral praktische vaardigheden zoals het toepassen van kennis en technieken in de praktijk en het oplossen van problemen volgens MBO'ers meer aandacht verdienen in de opleiding. Ook meer managementachtige vaardigheden zoals het plannen, coördineren en organiseren van activiteiten en het overdragen van kennis worden relatief vaak genoemd. Ondanks deze roep om meer aandacht voor de praktijk, geeft ook $37 \%$ aan meer aandacht voor de vakkennis wenselijk te vinden. Aan schrijfvaardigheid, vreemde talen en commerciële vaardigheden wordt volgens MBO'ers over het algemeen voldoende aandacht geschonken. ${ }^{3}$

3. Schoolverlaters van de verschillende niveaus en leerwegen oordelen opmerkelijk eensgezind over de accenten die in de opleiding worden gelegd. Zo vinden zowel BOL'ers als BBL'ers de toepassing van de theorie in de praktijk een onderbelicht aspect in de opleiding. Schoolverlaters van opleidingen op niveau 3 en 4 zijn over het algemeen wat kritischer over de opleiding dan schoolverlaters van opleidingen op niveau 1 en 2 . Voor de meeste aspecten geven hoger opgeleiden vaker aan dat het betreffende aspect meer aandacht verdient. 
Tabel 4.1

Percentage werkende MBO-schoolverlaters dat aangeeft dat aan een bepaald aspect meer aandacht zou moeten worden geschonken in opleiding, 2002

\begin{tabular}{lr}
\hline Aspect & $\%$ \\
\hline Vakkennis & 37 \\
Inzicht in informatie- en communicatietechnologie & 29 \\
Inzicht in bedrijfsvoering & 26 \\
Vreemde talen & 17 \\
Inzicht in milieu- en veiligheidsvoorschriften & 23 \\
Toepassen van kennis en technieken in de praktijk & 46 \\
Schrijfvaardigheid & 16 \\
Spreekvaardigheid & 23 \\
Overdragen van kennis & 37 \\
Plannen, coördineren en organiseren van activiteiten & 37 \\
Oplossen van problemen & 43 \\
Contactuele vaardigheden & 29 \\
Werken in teamverband & 29 \\
Commerciële vaardigheden & 18 \\
Zelfstandigheid & 35 \\
Initiatief, creativiteit & 34 \\
Aanpassingsvermogen & 22 \\
Nauwkeurigheid, zorgvuldigheid & 35 \\
\hline Brn: $R O A$ (RUBS) &
\end{tabular}

Bron: ROA (RUBS)

\section{Figuur 4.2}

Oordeel over de aansluiting tussen opleiding en vervolgopleiding in procenten naar opleidingssector, 2002 (oordeel 'voldoende' of 'goed')

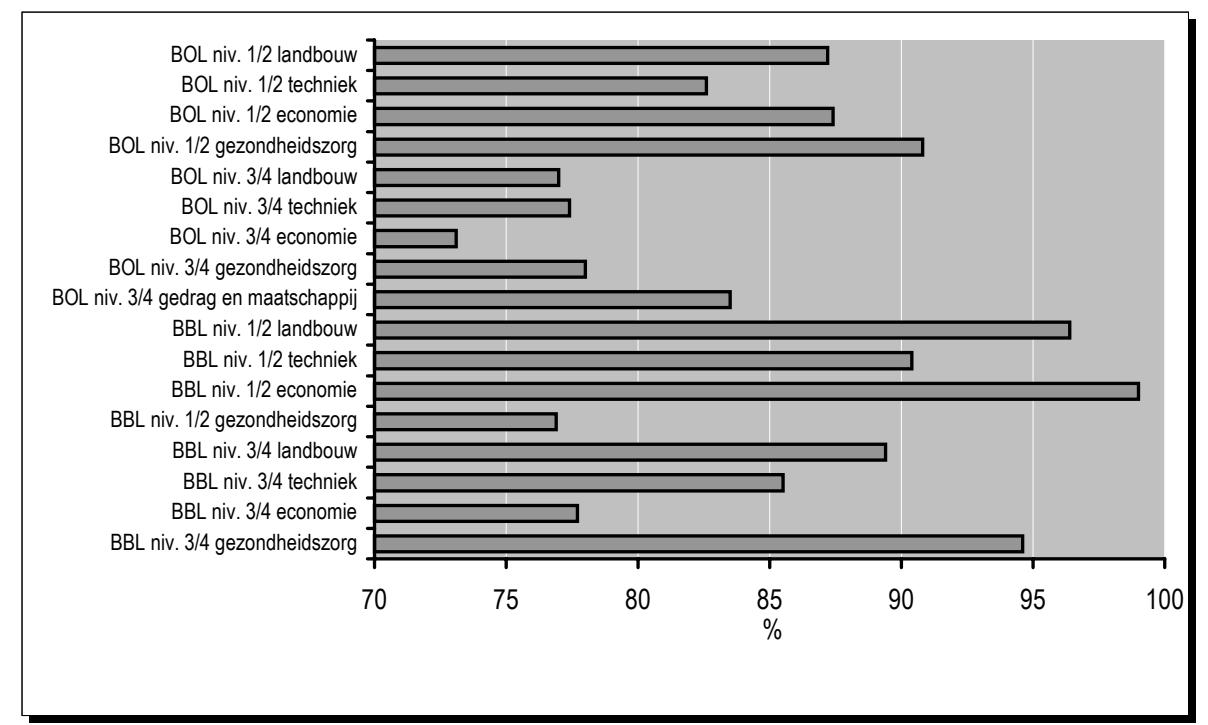

* Het aantal verder lerenden met als achtergrond een opleiding in de sector BBL niveau 3 en 4 gedrag en maatschappij is te klein om betrouwbare uitspraken te kunnen doen.

Bron: $R O A$ (RUBS) 
Ook tevredenheid over aansluiting met vervolgopleiding groot; BOL'ers niveau 3 en 4 het meest kritisch

Figuur 4.2 laat zien in hoeverre de doorlerende MBO'er de aansluiting tussen opleiding en beroepspraktijk als 'voldoende' of 'goed' ervaart. Ook hier is de tevredenheid groot. Meer dan $80 \%$ van de doorlerende MBO'ers is tevreden over de aansluiting tussen de afgeronde opleiding en de vervolgstudie. Schoolverlaters niveau 3 en 4 geven wat vaker aan ontevreden te zijn over de aansluiting dan schoolverlaters niveau 1 en 2. Dit geldt met name voor de BOL'ers. Dit beeld kan verschillende oorzaken hebben. Zo kiezen lager opgeleiden vaker voor een verwante opleiding dan met name BOL'ers niveau 3 en 4 . Het ligt voor de hand dat de overgang naar een niet-verwante opleiding moeizamer verloopt. Hoger opgeleiden hebben daarnaast de mogelijkheid om door te stromen naar het HBO. Met name BOL'ers blijken, zoals hoofdstuk 2 liet zien, hiervoor te kiezen. De stap naar een hoger opleidingsniveau leidt wellicht ook tot extra aansluitingsproblemen.

Met name doorlerende BBL'ers niveau 1 en 2 zijn zeer tevreden over de aansluiting. Zij kiezen vaak, wellicht in overleg met hun leerbedrijf, voor een verwante vervolgopleiding. De BBL'ers niveau 1 en 2 economie zijn zelfs bijna allemaal tevreden. De BBL'ers niveau 1 en 2 gezondheidszog zijn hierbij een opvallend buitenbeentje. Bijna een kwart geeft aan niet tevreden te zijn. Zoals gezegd zijn BOL'ers niveau 3 en 4 het minst tevreden. BOL'ers niveau 3 en 4 economie geven het vaakst aan ontevreden te zijn over de aansluiting bij de vervolgopleiding. Toch geeft nog bijna driekwart aan de aansluiting als 'voldoende' of 'goed' te ervaren.

\section{Bijna driekwart $\mathrm{MBO}$-schoolverlaters tevreden over huidige functie}

In hoeverre zit de MBO'er op zijn plek? De werksatisfactie is een belangrijke indicator voor het arbeidsmarktsucces van schoolverlaters. Tabel 4.3 toont de mate van tevredenheid met de huidige functie. Bijna driekwart van de MBO-schoolverlaters geeft aan (zeer) tevreden te zijn met de huidige functie. Economisch opgeleiden lijken wat minder tevreden dan hun collega's van andere opleidingssectoren. Mogelijk speelt het wat bredere karakter van economische opleidingen een rol. Het beroepsbeeld is voor deze brede opleidingen wat minder duidelijk en de schoolverlaters komen in een brede waaier van beroepen terecht. De kans op teleurstellingen is daarmee wellicht wat groter. Zorgopgeleiden en schoolverlaters van opleidingen van de sector gedrag en maatschappij zijn relatief tevreden met hun huidige baan. Met name zorgopgeleiden hebben een duidelijk beeld van de beroepen en instellingen waarin zij terecht komen. Bovendien is hun arbeidsmarktpositie rooskleurig. De beloning en de werkzekerheid zijn hoog en de aansluiting tussen opleiding en beroepspraktijk is over het algemeen goed. 
Figuur 4.3

Tevredenheid met de huidige functie in procenten naar opleidingssector, 2002 (oordeel 'tevreden' of 'zeer tevreden')

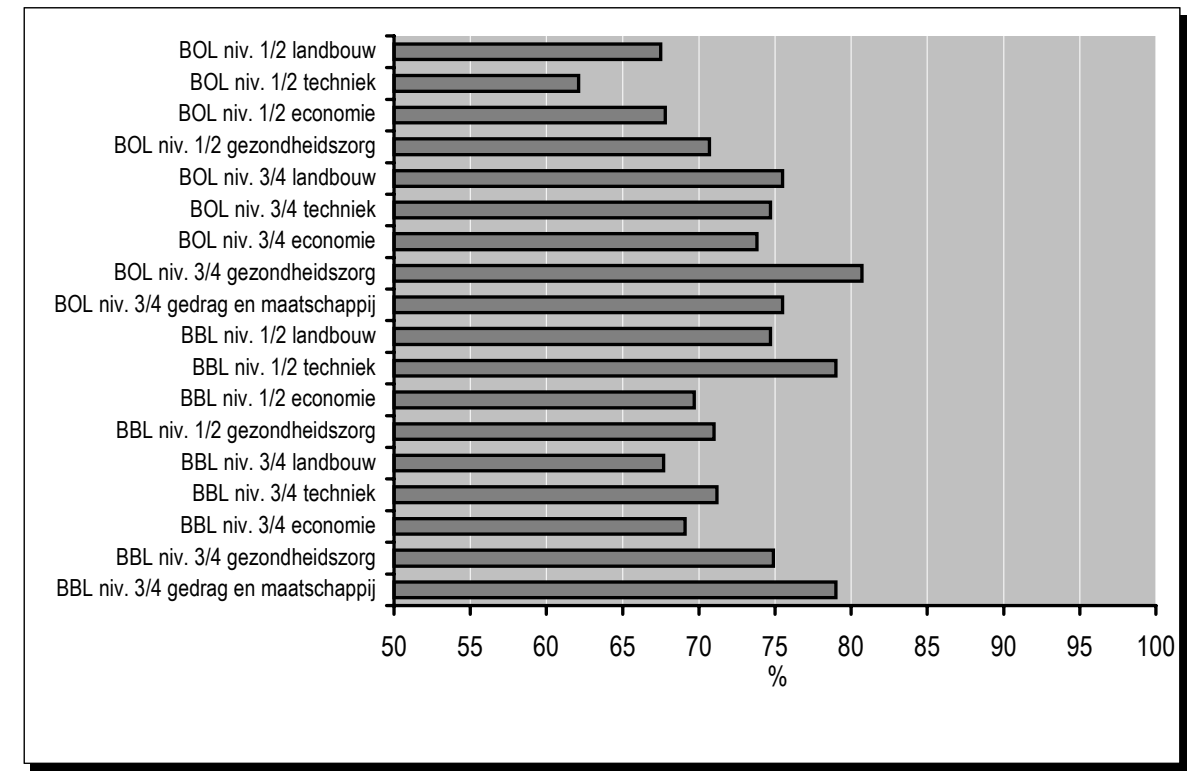

Bron: ROA (RUBS)

Figuur 4.4

Percentage MBO-schoolverlaters dat de laatste vier weken actief op zoek is geweest naar (ander) werk naar opleidingssector, 2002

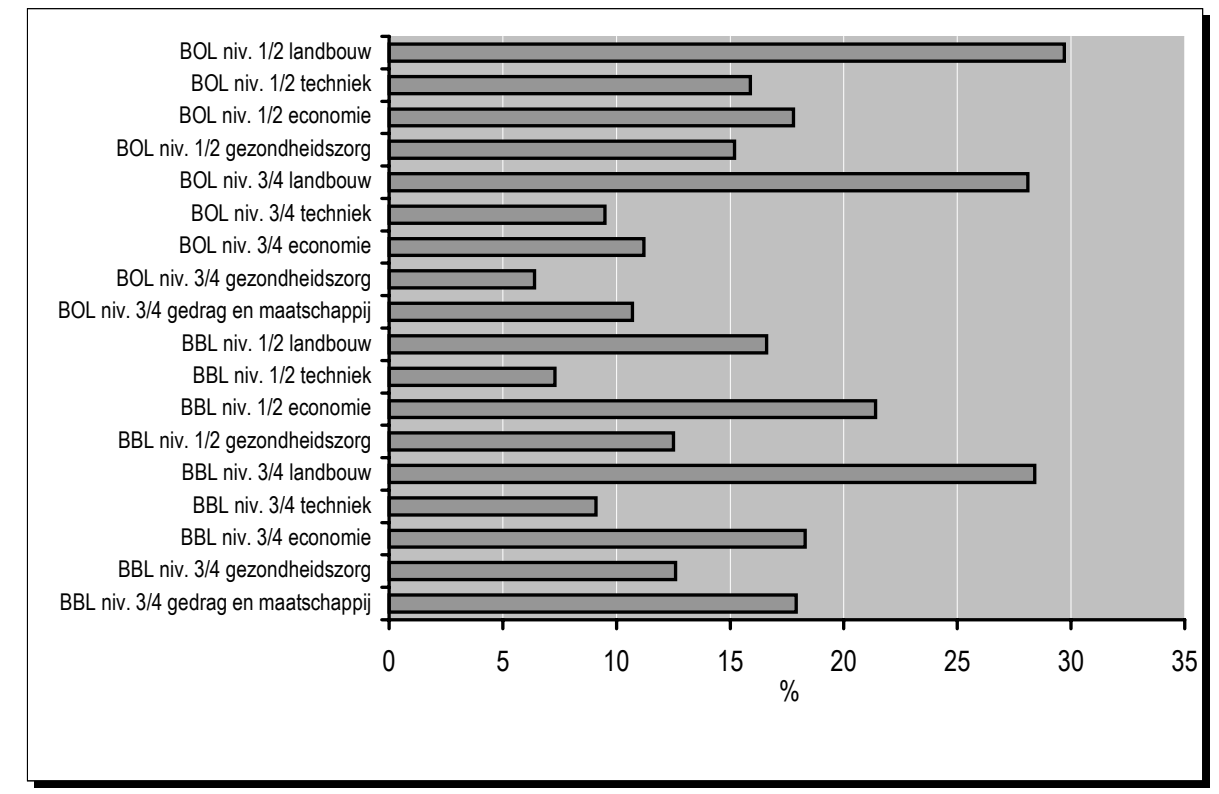

Bron: ROA (RUBS) 
Ruim 12\% MBO-schoolverlaters op zoek naar (ander) werk

Een geringe werksatisfactie hoeft echter niet te leiden tot het actief zoeken naar ander werk. Het al dan niet op zoek zijn naar (ander) werk kan gezien worden als een meer zichtbare indicator voor de tevredenheid met de huidige situatie. Het kan hierbij gaan om een MBO-schoolverlater, die op dit moment werk heeft, maar (al dan niet gedwongen) op zoek is naar ander werk. Het kan ook een student betreffen die overweegt zijn studie te beëindigen en actief op zoek is naar een baan. Een derde groep vormen uiteraard de werklozen die actief naar werk zoeken. In alle drie gevallen kunnen we spreken van MBO-schoolverlaters die niet tevreden zijn met hun huidige situatie en het gevoel hebben niet op hun plek te zitten. Figuur 4.4 geeft een overzicht van het aantal MBO-schoolverlaters dat de laatste vier weken actief op zoek naar (ander) werk is geweest. Ruim 12\% antwoordt bevestigend op deze vraag. De tabel laat verder een gevarieerd beeld zien. De landbouwopleidingen springen het meest in het oog. Met uitzondering van de BBL'ers niveau 1 en 2 is bijna $30 \%$ van de agrarisch opgeleiden op zoek naar (ander) werk. Opvallend is verder het aantal actieve zoekers bij de schoolverlaters van economische opleidingen. Zo is meer dan $20 \%$ van de BBL'ers niveau 1 en 2 economie op zoek naar (ander) werk. Bij de BOL'ers niveau 1 en 2 en de BBL'ers niveau 3 en 4 is dit ongeveer $18 \%$. We hebben in figuur 4.3 al gezien dat werkend economisch opgeleiden relatief ontevreden zijn met hun huidige baan. Technisch opgeleiden zijn daarentegen relatief honkvast. Dit geldt met name voor de schoolverlaters van opleidingen op niveau 3 en 4. Ruim $9 \%$ van zowel de BOL'ers als de BBL'ers niveau 3 en 4 techniek zijn op zoek naar (ander) werk.

\section{Kwaliteit aansluiting beroep en opleiding heeft beperkte invloed op zoekgedrag}

Zoals gezegd, kan het op zoek zijn naar ander werk gezien worden als een indicator voor de tevredenheid met de huidige situatie. De vraagt rijst nu in hoeverre de aansluiting tussen opleiding en beroepspraktijk van invloed is op de wens van MBO'ers om van baan te veranderen. In tabel 4.2 wordt gekeken in hoeverre MBO'ers die werkzaam zijn beneden hun niveau vaker op zoek zijn naar ander werk. We kijken hierbij alleen naar degenen met een vaste aanstelling. Alleen zo kan het effect van de aansluiting goed gemeten worden. Schoolverlaters met een tijdelijke aanstelling zijn immers per definitie vaker op zoek naar ander werk. De tabel laat zien dat MBO-schoolverlaters die beneden hun niveau werkzaam zijn, inderdaad vaker op zoek zijn naar ander werk. Het verschil is echter niet zo groot. Van degenen die onder hun niveau werkzaam zijn, is $13 \%$ op zoek naar ander werk. Van de MBO'ers die een baan hebben gevonden waarvoor de werkgever minstens een MBO-diploma vereist, is $10 \%$ actief op zoek naar ander werk. De tabel laat bovendien zien dat er een duidelijk verschil is tussen BOL'ers en BBL'ers. Alleen bij BOL'ers heeft de aansluiting naar niveau gevolgen voor de inspanningen die worden gepleegd om een andere baan te vinden. Wellicht zijn BBL'ers door hun grotere werkervaring al beter in staat gebleken een baan te verwerven die goed aansluit bij hun wensen en capaciteiten (hoewel dat in de objectieve maatstaven niet altijd tot uiting komt). 
In tabel 4.3 wordt gekeken in hoeverre schoolverlaters die buiten hun eigen richting terecht zijn gekomen vaker op zoek zijn naar ander werk. Ook nu wordt alleen gekeken naar degenen die een vaste aanstelling hebben. De tabel laat zien dat een gebrekkige aansluiting naar richting vaker leidt tot de wens om van baan te veranderen. Terwijl 9\% van de MBO'ers die een baan in de eigen richting hebben gevonden actief op zoek is naar ander werk, is dat bij degenen die buiten hun eigen richting terecht zijn gekomen meer dan het dubbele: $17 \%$. Opnieuw is er een verschil tussen BOL'ers en BBL'ers. Bij BOL'ers niveau 1 en 2 is éénvijfde van degenen die buiten de eigen richting werkzaam zijn actief op zoek naar ander werk. Dit is bijna het drievoudige van degenen die wel emplooi hebben gevonden binnen de eigen richting. Bij BBL'ers niveau 3 en 4 lijkt de aansluiting naar richting er niet toe te doen. Opvallend is het gedrag van BBL'ers niveau 1 en 2. Daar waar tabel 4.2 liet zien dat de aansluiting naar niveau geen invloed lijkt de hebben op het zoekgedrag, is de aansluiting naar richting wel van belang.

Tabel 4.2

Percentage werkende MBO'ers met een vaste aanstelling op zoek naar ander werk naar leerweg, niveau en aansluiting naar niveau, 2002

\begin{tabular}{|c|c|c|}
\hline \multirow[t]{2}{*}{ Opleidingssector } & \multicolumn{2}{|c|}{ Werkzaam onder niveau? } \\
\hline & Nee & $\mathrm{Ja}$ \\
\hline $\begin{array}{l}\text { BOL niveau } 1 \text { en } 2 \\
\text { BOL niveau } 3 \text { en } 4 \\
\text { BBL niveau } 1 \text { en } 2 \\
\text { BBL niveau } 3 \text { en } 4\end{array}$ & $\begin{array}{r}8 \\
8 \\
10 \\
12\end{array}$ & $\begin{array}{r}15 \\
16 \\
9 \\
13\end{array}$ \\
\hline Totaal & 10 & 13 \\
\hline
\end{tabular}

Bron: ROA (RUBS)

Tabel 4.3

Percentage werkende MBO'ers met een vaste aanstelling op zoek naar ander werk naar leerweg, niveau en aansluiting naar richting, 2002

\begin{tabular}{lcc}
\hline Opleidingssector & \multicolumn{2}{c}{ Werkzaam buiten eigen richting? } \\
\cline { 2 - 3 } & Nee & Ja \\
\hline BOL niveau 1 en 2 & 7 & 20 \\
BOL niveau 3 en 4 & 8 & 19 \\
BBL niveau 1 en 2 & 7 & 16 \\
BBL niveau 3 en 4 & 12 & 11 \\
Totaal & 9 & 17 \\
\hline
\end{tabular}

Bron: ROA (RUBS)

Een relativerende opmerking is bij de cijfers gepresenteerd in de tabellen 4.2 en 4.3 op zijn plaats. Ondanks het geconstateerde effect van een minder goede aansluiting op het zoekgedrag van MBO-schoolverlaters, laten de cijfers ook zien dat maar liefst $87 \%$ van degenen die onder hun niveau werkzaam zijn en $83 \%$ van degenen die 
buiten hun 'eigen' beroependomein werken dat niet als een acuut probleem beschouwen en dus niet actief op zoek zijn naar ander werk.

\section{Ongeveer driekwart MBO-schoolverlaters achteraf tevreden over studiekeuze}

De studiekeuze heeft een belangrijke invloed op de latere (beroeps)loopbaan. Spijt achteraf over de studiekeuze is daarom een derde belangrijke indicator voor de tevredenheid met de huidige situatie. Werkenden geven hiermee aan dat ze wellicht een andere werkplek voor ogen hebben gehad toen zij aan de studie begonnen. De verder lerende schoolverlater kan spijt hebben van zijn keuze omdat hij niet tevreden is over de afgesloten opleiding en de opleiding die hij nu volgt. Figuur 4.5 laat zien in hoeverre MBO-schoolverlaters achteraf gezien tevreden zijn over de keuze voor de recent afgesloten opleiding. Ruim driekwart van hen zou opnieuw voor dezelfde opleiding kiezen. Er zijn enkele opvallende verschillen tussen de opleidingssectoren. BBL'ers niveau 3 en 4 zijn het meest tevreden. Dit is niet zo verrassend. BBL'ers niveau 3 en 4 hebben een sterke arbeidsmarktpositie vergeleken met andere MBO'ers. Zo worden zij minder vaak geconfronteerd met werkloosheid en hebben ze relatief vaak een vast contract. BOL'ers niveau 1 en 2 zijn het minst vaak tevreden. Slechts $60 \%$ van de BOL'ers niveau 1 en 2 gezondheidszorg zou bijvoorbeeld opnieuw voor dezelfde opleiding kiezen.

\section{Figuur 4.5}

Percentage MBO-schoolverlaters dat de afgesloten opleiding achteraf bezien opnieuw zou volgen naar opleidingssector, 2002

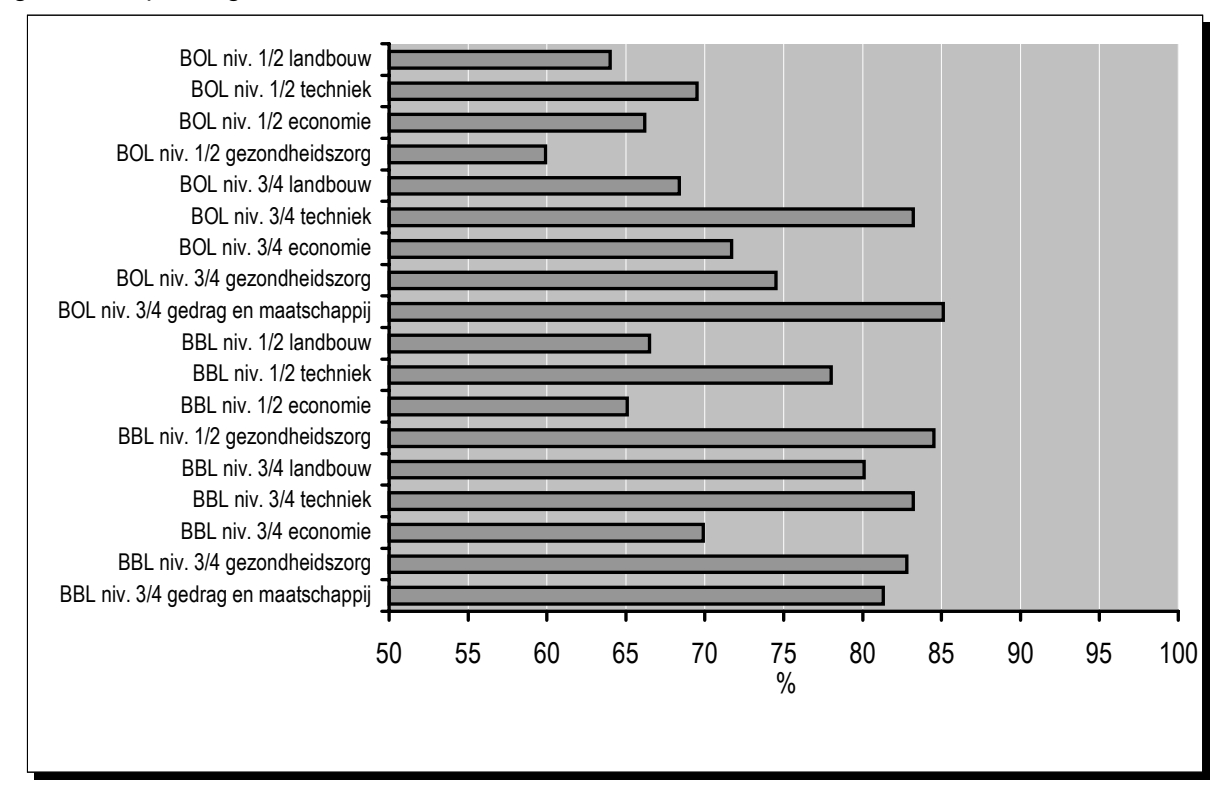

Bron: ROA (RUBS)

\section{Goede aansluiting beroep en opleiding heeft positief effect op tevredenheid}

In tabel 4.4 wordt, analoog aan tabel 4.2 , gekeken naar de invloed van het baanniveau op de tevredenheid met de studiekeuze. Tabel 4.4 laat een vergelijkbaar 
beeld zien als tabel 4.2. De aansluiting naar niveau heeft invloed. MBO-schoolverlaters die op hun niveau werkzaam zijn kijken met meer tevredenheid (78\%) terug op hun opleiding dan schoolverlaters die beneden hun niveau emplooi hebben gevonden (71\%). Opnieuw zien we ook dat het effect bij BBL'ers kleiner is dan bij BOL'ers. We zien daarnaast ook dat het effect bij de lager opgeleiden groter is dan bij schoolverlaters van niveau 3 en 4 .

Tabel 4.5 laat zien in hoeverre de aansluiting naar richting invloed heeft op de tevredenheid achteraf over de studiekeuze. Het beeld is vergelijkbaar met hetgeen we hebben gezien in tabel 4.3. Schoolverlaters die een baan in de eigen richting hebben gevonden, zijn meer tevreden dan mensen die buiten het eigen beroependomein werkzaam zijn. Binnen het eigen domein is bijna $80 \%$ tevreden, terwijl buiten het eigen domein bijna tweederde van de schoolverlaters aangeeft achteraf tevreden te zijn over de studiekeuze. Opnieuw is het effect bij BOL'ers niveau 1 en 2 het grootst, terwijl bij BBL'ers niveau 3 en 4 de aansluiting tussen opleiding en beroepspraktijk er nauwelijks toe lijkt te doen.

Tabel 4.4

Percentage werkende MBO'ers dat de afgesloten opleiding achteraf bezien opnieuw zou volgen naar leerweg, niveau en aansluiting naar niveau, 2002

\begin{tabular}{lcc}
\hline Opleidingssector & \multicolumn{2}{l}{ Werkzaam onder niveau? } \\
\cline { 2 - 3 } & Nee & Ja \\
\hline BOL niveau 1 en 2 & 67 & 55 \\
BOL niveau 3 en 4 & 77 & 71 \\
BBL niveau 1 en 2 & 80 & 70 \\
BBL niveau 3 en 4 & 83 & 80 \\
Totaal & 78 & 71 \\
\hline
\end{tabular}

Bron: ROA (RUBS)

Tabel 4.5

Percentage werkende MBO'ers dat de afgesloten opleiding achteraf bezien opnieuw zou volgen naar leerweg, niveau en aansluiting naar richting, 2002

\begin{tabular}{lcc}
\hline Opleidingssector & \multicolumn{2}{c}{ Werkzaam buiten eigen richting? } \\
\cline { 2 - 3 } & Nee & Ja \\
\hline BOL niveau 1 en 2 & 71 & 52 \\
BOL niveau 3 en 4 & 79 & 65 \\
BBL niveau 1 en 2 & 80 & 64 \\
BBL niveau 3 en 4 & 82 & 79 \\
Totaal & 79 & 65 \\
\hline
\end{tabular}

Bron: ROA (RUBS)

In hoofdstuk 3 is reeds opgemerkt dat bij de opleidingen op niveau 1 en 2 een minder goede aansluiting tussen de opleiding en de beroepspraktijk veelal betekent dat de schoolverlaters terechtkomen op de zogenaamde 'secundaire arbeidsmarkt'. Bij de 
opleidingen op niveau 3 en 4 kan het juist betekenen dat de zij breed inzetbaar zijn en vanuit een wat minder gunstige startpositie mogelijk toch een goed carrièreperspectief hebben. Het is daarom niet zo verrassend dat vooral schoolverlaters van niveau 1 en 2 ontevreden zijn wanneer zij in een baan terechtkomen die minder goed aanluit bij de opleiding.

\section{Figuur 4.6}

Tevredenheid met de studie- en beroepskeuzevoorlichting in procenten naar opleidingssector, 2002 (oordeel 'tevreden' of 'zeer tevreden')

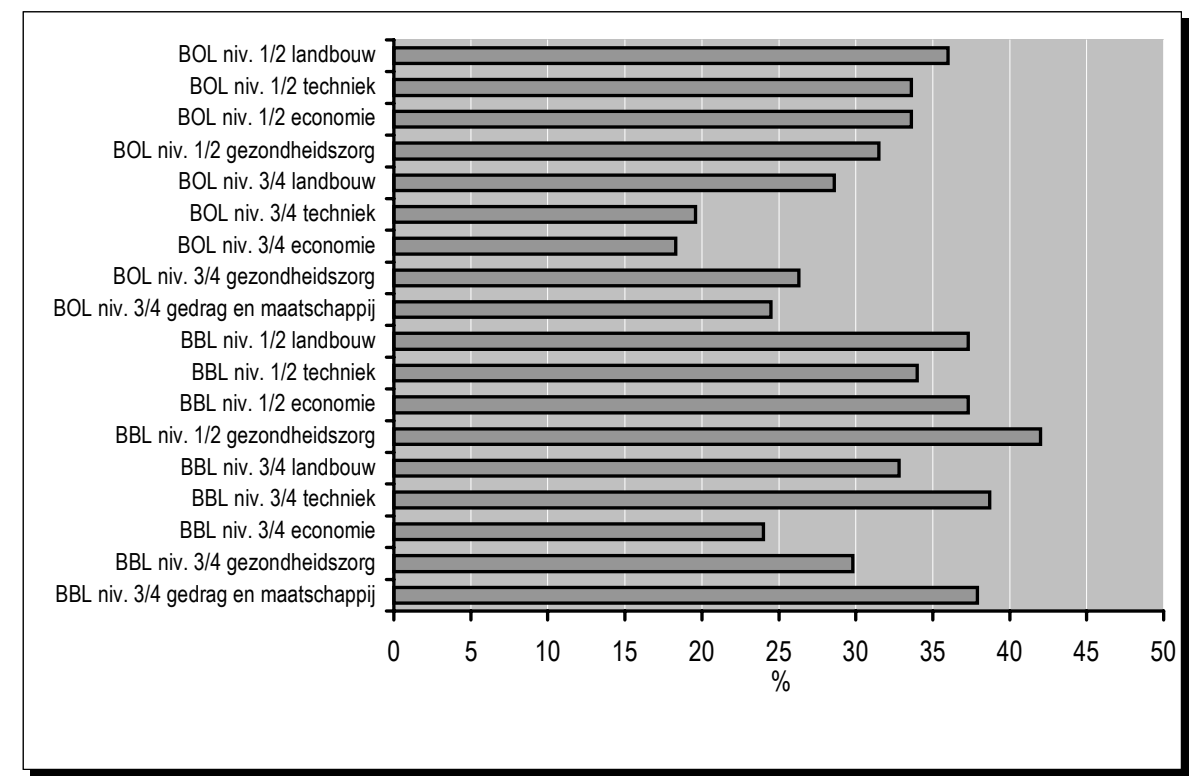

Bron: ROA (RUBS)

\section{BOL'ers niveau 3 en 4 relatief ontevreden over studie- en beroepskeuzevoorlichting}

MBO-opleidingen beogen leerlingen een goede basis te bieden voor de latere school- en beroepsloopbaan. Een goede voorlichting over de kansen en mogelijkheden op de arbeidsmarkt en voor eventuele vervolgopleidingen kan hierbij een belangrijke rol spelen. Aan de schoolverlaters is gevraagd in hoeverre zij tevreden zijn over de hulp die zij van de school hebben gehad bij de keuze van een vervolgopleiding of een beroep. Figuur 4.6 toont aan dat ongeveer $30 \%$ van de MBO'ers (zeer) tevreden is over de studie- en beroepskeuzevoorlichting. Met name BOL'ers niveau 3 en 4 vallen in negatieve zin op. Aanzienlijk minder dan 30\% (met uitzondering van de agrarisch opgeleiden) van de schoolverlaters BOL-opleidingen op niveau 3 en 4 is tevreden over de studie- en beroepskeuzevoorlichting. BOL'ers niveau 3 en 4 economie zijn het minst tevreden. Slechts $18 \%$ geeft aan (zeer) tevreden te zijn met de studie- en beroepskeuzevoorlichting. De ontevredenheid van BOL'ers niveau 3 en 4 kan verschillende oorzaken hebben. BOL'ers hebben wellicht meer mogelijkheden. Zo zijn zij wat minder beroepsspecifiek opgeleid en kiezen zij ook vaker voor het HBO. Deze grotere mogelijkheden maken echter tegelijkertijd de keuze complexer en de behoefte aan begeleiding groter. Een tweede verklaring zou 
kunnen zijn dat scholen meer aandacht schenken aan kwetsbare groepen die met name opleidingen op niveau 1 en 2 volgen. Dit zou kunnen verklaren dat BBL'ers niveau 1 en 2 gemiddeld genomen het meest tevreden zijn. Zo is van de BBL'ers niveau 1 en 2 gezondheidszorg maar liefst $42 \%$ (zeer) tevreden over de voorlichting. 



\section{$5 \quad$ MBO'ers en de economische onzekerheid}

De arbeidsmarktpositie van opleidingen wordt voor een belangrijk deel bepaald door de verhouding tussen vraag en aanbod op de arbeidsmarkt. De conjunctuur heeft invloed op deze verhoudingen en beïnvloedt daarmee de kansen op de arbeidsmarkt. Conjunctuurschommelingen hebben echter niet op alle segmenten van de arbeidsmarkt dezelfde impact. Bepaalde segmenten van de arbeidsmarkt kunnen worden gekenschetst als zeer conjunctuurgevoelig, terwijl de werkgelegenheid in andere segmenten nauwelijks wordt beïnvloed door de (macro)economische ontwikkeling. Mede in het licht van de huidige onzekere economische situatie, staan we in deze paragraaf stil bij de vraag hoe vatbaar de werkgelegenheid voor MBOschoolverlaters is voor conjuncturele schommelingen in vergelijking met andere groepen op de arbeidsmarkt. Grofweg kunnen verschillen in de conjunctuurgevoeligheid van de werkgelegenheid twee oorzaken hebben:

1. verschillen in vatbaarheid van de werkgelegenheid voor conjuncturele schommelingen tussen $\mathrm{MBO}$-schoolverlaters en andere groepen op de arbeidsmarkt;

2. afhankelijkheid van de werkgelegenheid in specifieke bedrijven en beroepen die erg gevoelig of juist ongevoelig zijn voor conjuncturele schommelingen.

Aan de verschillen in vatbaarheid voor conjuncturele schommelingen tussen groepen op de arbeidsmarkt kunnen allerlei factoren ten grondslag liggen. Zo ligt het voor de hand te veronderstellen dat groepen die vaker met een tijdelijke aanstelling werkzaam zijn bij een economische achteruitgang een groter risico lopen hun baan te verliezen. In tabel 5.1 wordt een overzicht gegeven van het totaal aantal tijdelijke arbeidskrachten met een MBO-diploma en het aantal schoolverlaters met een tijdelijk contract naar MBO-opleidingscategorie. Uit de tabel blijkt dat schoolverlaters veel vaker met een tijdelijk arbeidscontract aan het werk zijn. ${ }^{4}$ Met name voor de economisch en technisch opgeleiden is het verschil groot. Blijkbaar kijken werkgevers die jonge technisch en economisch opgeleide MBO'ers in dienst nemen vaker de kat uit de boom. Dit maakt economisch en technisch opgeleiden kwetsbaar wanneer bedrijven en instellingen bij economische tegenwind zich genoodzaakt zien tot reorganisaties over te gaan. Met andere woorden: het feit dat MBOschoolverlaters vaker met een tijdelijk contract werkzaam zijn dan hun meer ervaren collega's met een MBO-diploma, maakt hen mogelijk kwetsbaarder in tijden van economische onzekerheid.

4. Opgemerkt dient te worden dat de cijfers voor alle MBO'ers gemiddelden voor 2000 en 2001 betreffen. Hoofdstuk 3 heeft laten zien dat het aantal tijdelijke aanstellingen voor schoolverlaters een verder dalende trend vertoont. Het verschil tussen schoolverlaters en meer ervaren MBO'ers zou dus nog hoger kunnen uitvallen. 
Tabel 5.1

Aantal MBO-schoolverlaters met een tijdelijk arbeidscontract (2002) en totaal aantal MBO'ers met een tijdelijk arbeidscontract (gemiddelde 2000-2001) in procenten

\begin{tabular}{|c|c|c|}
\hline Opleidingscategorie & $\begin{array}{c}\text { MBO- } \\
\text { schoolverlaters }\end{array}$ & $\begin{array}{c}\text { Alle werkende } \\
\text { MBO'ers }\end{array}$ \\
\hline MBO landbouw en natuurlijke omgeving & 14 & 7 \\
\hline MBO Techniek & 13 & 4 \\
\hline MBO Dienstverlening en gezondheidszorg & 12 & 8 \\
\hline MBO Economie & 24 & 6 \\
\hline MBO Totaal & 16 & 6 \\
\hline
\end{tabular}

In de rest van deze paragraaf richten we ons op het tweede aspect en stellen we de vraag in hoeverre de bedrijven en beroepen waarin MBO-schoolverlaters werkzaam zijn de werkgelegenheid voor MBO-schoolverlaters gevoeliger of juist minder gevoelig maakt voor veranderingen in de conjunctuur. ${ }^{5}$ Tabel 5.2 geeft inzicht in de bedrijfssectoren waarin MBO-schoolverlaters terechtkomen. Tegelijkertijd wordt een vergelijking gemaakt met de werkgelegenheidstructuur naar bedrijfssector van de totale Nederlandse arbeidsmarkt. De tabel laat zien dat deze vergelijking nogal wat verschillen oplevert. MBO-schoolverlaters komen relatief vaak in de conjunctuurgevoelige bouwsector terecht. In de sector overheid en onderwijs, waarin de werkgelegenheid veel minder gevoelig is voor conjuncturele schommelingen, zijn MBOschoolverlaters relatief weinig terug te vinden. Deze verschillen kunnen toegeschreven worden aan het feit dat (jonge) schoolverlaters in andere sectoren werk vinden dan meer ervaren collega's. De bouw, de handel en de horeca zijn typische voorbeelden van bedrijfssectoren die veel jonge MBO'ers in dienst nemen. Daarnaast speelt een rol dat bepaalde sectoren veel behoefte hebben aan MBO'ers (ongeacht hun leeftijd), terwijl andere sectoren vaker een beroep doen op hoger opgeleiden. De overheid en het onderwijs zijn typische voorbeelden van bedrijfssectoren die relatief weinig behoefte hebben aan MBO'ers.

Wat betekent dit voor de gevoeligheid van de werkgelegenheid van MBO-schoolverlaters voor conjuncturele schommelingen? Tabel 5.3 tracht hierin inzicht te geven. De tabel geeft een overzicht van het percentage schoolverlaters dat emplooi heeft gevonden in banen die als conjunctuurgevoelig of juist als ongevoelig voor conjuncturele schommelingen kunnen worden getypeerd. Uit de tabel blijkt dat ruim $40 \%$ van de MBO-schoolverlaters werkzaam is bedrijfssectoren en beroepen waarin de werkgelegenheid gevoelig is voor conjuncturele schommelingen. Zoals tabel 5.2 heeft laten zien, kan hierbij worden gedacht aan banen in de bouw, de handel, de

5. Hierbij staat de indicator voor de conjunctuurgevoeligheid centraal. Bij het bepalen van de conjunctuurgevoeligheid wordt impliciet verondersteld dat de conjunctuurgevoeligheid van de werkgelegenheid voor schoolverlaters niet afwijkt van het totale beeld. Enerzijds is dit een beperking, aangezien er geen rekening wordt gehouden met het specifieke karakter van de werkgelegenheid voor schoolverlaters. Met andere woorden de eerste oorzaak van verschillen in de conjunctuurgevoeligheid zoals hierboven genoemd wordt uitgesloten. Anderzijds biedt het de mogelijkheid het effect van verschillen in het type banen (de tweede oorzaak) zuiver te meten. 
horeca en de zakelijke dienstverlening. Bijna 20\% komt terecht in bedrijven en beroepen waarin de werkgelegenheid relatief ongevoelig is voor de conjunctuur. Hierbij kan worden gedacht aan banen in de agrarische sector, delen van de industrie, bij de overheid en in het onderwijs.

Tabel 5.2

De werkgelegenheidsstructuur naar bedrijfssector voor MBO-schoolverlaters (2002) en voor de gehele arbeidsmarkt (gemiddelde 2000-2001) in procenten en een typering van de conjunctuurgevoeligheid van de werkgelegenheid

\begin{tabular}{|c|c|c|c|}
\hline Bedrijfssector & $\begin{array}{c}\mathrm{MBO}- \\
\text { schoolverlaters } \\
\%\end{array}$ & $\begin{array}{c}\text { Alle } \\
\text { werkenden } \\
\%\end{array}$ & $\begin{array}{l}\text { Typering } \\
\text { conjunctuur- } \\
\text { gevoeligheid }\end{array}$ \\
\hline Landbouw en visserij & 3 & 3 & Erg laag \\
\hline Voeding & 1 & 2 & Laag \\
\hline Chemie & 1 & 2 & Gemiddeld \\
\hline Metaal en elektrotechniek & 4 & 6 & Gemiddeld \\
\hline Overige industrie & 3 & 5 & Hoog \\
\hline Energie & 1 & 1 & Gemiddeld \\
\hline Bouw en onroerend goed & 15 & 8 & Hoog \\
\hline Handel en reparatie & 17 & 15 & Hoog \\
\hline Transport en communicatie & 4 & 6 & Gemiddeld \\
\hline Bank- en verzekeringswezen & 2 & 4 & Gemiddeld \\
\hline Horeca en zakelijke dienstverlening & 17 & 16 & Erg hoog \\
\hline Quartaire diensten & 27 & 16 & Gemiddeld \\
\hline Overheid en onderwijs & 5 & 14 & Laag \\
\hline
\end{tabular}

Bron: ROA (RUBS/POA)/CBS (EBB)

Tabel 5.3

Typering conjunctuurgevoeligheid van de werkgelegenheid voor MBO-schoolverlaters naar opleidingscategorie in procenten, 2002

\begin{tabular}{lcc}
\hline \multirow{2}{*}{ Opleidingscategorie } & \multicolumn{2}{c}{ Typering conjunctuurgevoeligheid } \\
\cline { 2 - 3 } & (erg) laag & (erg) hoog \\
\hline MBO landbouw en natuurlijke omgeving & 64 & 0 \\
MBO Techniek & 3 & 40 \\
MBO Dienstverlening en gezondheidszorg & 4 & 76 \\
MBO Economie & 50 & 0 \\
MBO Totaal & 18 & 42
\end{tabular}

Bron: ROA (POA/RUBS)

De verschillen tussen de opleidingscategorieën zijn opvallend groot. $\mathrm{Er}$ is duidelijk sprake van een tweedeling. Aan de ene kant vinden we de agrarische en economische opleidingen. Dat agrarisch opgeleiden in een minder gunstige situatie niet zo snel voor hun baan hoeven te vrezen is niet zo verrassend, aangezien zij voor een belangrijk deel in de conjunctuurongevoelige agrarische sector emplooi vinden. Economisch opgeleiden komen in een breed scala aan bedrijven en beroepen terecht. Dit impliceert dat zij in ieder geval relatief minder afhankelijk zijn van de ontwikkelingen in conjunctuurgevoelige bedrijfssectoren. 
Aan de andere kant vinden we de technisch opgeleiden en de schoolverlaters van de opleidingscategorie dienstverlening en gezondheidszorg. Hun positie is een stuk kwetsbaarder. Technisch opgeleiden komen relatief vaak terecht in de conjunctuurgevoelige bouw en de industrie. De conjunctuurgevoelige handel, horeca en zakelijke dienstverlening bieden vaak werk voor schoolverlaters met een dienstverlenende opleiding. Deze kwetsbare positie betekent overigens niet vanzelfsprekend dat de desbetreffende groep werkloos zal worden, wanneer het economisch minder gaat. Het kan ook leiden tot een toename van flexibele arbeidscontracten, stagnerende lonen of het vaker onder niveau of buiten de richting werken.

Concluderend kan gesteld worden dat MBO-schoolverlaters in een situatie van economische tegenwind relatief kwetsbaar zijn op de arbeidsmarkt. Dit heeft twee oorzaken. Op de eerste plaats hebben schoolverlaters relatief vaak een tijdelijk contract. Op de tweede plaats vinden MBO-schoolverlaters relatief vaak werk in conjunctuurgevoelige bedrijfssectoren als de bouw, de handel, de horeca en de zakelijke dienstverlening, terwijl in sectoren als de overheid en het onderwijs, die veel minder conjunctuurgevoelig zijn, de kansen voor MBO-schoolverlaters relatief klein zijn. Dit geldt met name voor technisch opgeleiden en schoolverlaters van dienstverlenende opleidingen. De keerzijde is dat, wanneer het aantal banen weer groeit, MBO-schoolverlaters erg gewild zijn en ten volle en wellicht sterker dan andere groepen op de arbeidsmarkt kunnen profiteren van een aantrekkende economie. 